\title{
Sezonowa i wieloletnia zmienność niektórych elementów klimatu w Tatrach i Karkonoszach w latach 1951-2015 Seasonal and multiannual variability of selected elements of climate in the Tatra and Karkonosze Mts over the 1951-2015 period
}

\author{
Krzysztof Błażejczyk \\ Instytut Geografii i Przestrzennego Zagospodarowania im. S. Leszczyckiego PAN \\ ul. Twarda 51/55, 00-818 Warszawa \\ k.blaz@twarda.pan.pl
}

Zarys treści. W ostatnich dekadach XX w. i na początku XXI w. obserwuje się w skali globalnej znaczący wzrost temperatury powietrza. W odniesieniu do pozostałych elementów klimatu informacje są rozbieżne. Na przykład, relacjonowany jest wzrost opadów lub ich zmniejszanie. Brak jest praktycznie informacji, czy i w jakim stopniu zmieniają się wilgotność powietrza i prędkość wiatru. Obszary górskie są miejscami szczególnie wrażliwymi na zmiany klimatu. Dlatego też w opracowaniu tym podjęto próbę porównania sezonowych i wieloletnich zmian niektórych elementów klimatu i wskaźników klimatycznych w polskich wysokich górach (Tatry i Karkonosze) w latach 1951-2015. Stwierdzono szereg podobieństw i różnic klimatycznych pomiędzy badanymi pasmami, zwłaszcza w odniesieniu do gradientów wysokościowych temperatury powietrza (gradient średniej rocznej temperatury powietrza wynosi $-0,53^{\circ} \mathrm{C}$ w Tatrach i $-0,55^{\circ} \mathrm{C}$ na $100 \mathrm{~m}$ wzniesienia w Karkonoszach $)^{1}$ i pokrywy śnieżnej (10 cm/100 m w Tatrach i 12 cm/100 m w Karkonoszach). Opady atmosferyczne cechują się gradientem wysokościowym 38 mm/100 m w Karkonoszach i 53 mm/100 m w Tatrach. Stwierdzono także podobieństwa i różnice tempa zmian różnych elementów klimatu w analizowanym wieloleciu. W przypadku średniej rocznej temperatury istotny trend zmian wynosi w obydwu pasmach około $0,3^{\circ} \mathrm{C}$ na 10 lat. W większości przypadków zmiany charakterystyk opadowych oraz dotyczących pokrywy śnieżnej są nieistotne statystycznie.

Słowa kluczowe: klimat, zmiany klimatu, Tatry, Karkonosze.

\section{Wstęp}

Obszary górskie są ekosystemami szczególnie wrażliwymi na wahania i zmiany klimatu (Trepińska, 2002; Migała, 2005). Środowisko górskie, a zwłaszcza wysokogórskie, stanowi system wzajemnie powiązanych elementów biotycznych, abiotycznych i atmosferycznych (Barry i van Wie, 1974; Yoshino, 1984; Kozłowska i Rączkowska, 1996, 1999). Ekstremalne sytuacje pogodowe (np. intensywne opady, fale ciepła, fale mrozów, silne wiatry) potrafią skutecznie, niekiedy w sposób trwały, przekształcić rzeźbę (przebieg i profil dolin, profile zboczy) czy pokrywę roślinną (Baranowski, 1999, 2003a, 2003b; Kotarba, 2013; Kozłowska, 2013; Rączkowska, 2013).

Badania cech klimatu i jego zmian w Karkonoszach i Tatrach są prowadzone od wielu lat. Powstało na ten temat szereg prac, spośród których można wymienić fundamentalne

\footnotetext{
${ }^{1}$ Gradient ujemny oznacza spadek wartości danej zmiennej wraz z wysokością.
} 
opracowanie klimatu Tatr (Konček, 1974) czy też atlas tego pasma górskiego (Dąbrowska i Guzik, 2015). W przypadku Karkonoszy należy wskazać publikację K. Migały i J. Czerwińskiego (2004) czy monograficzny rozdział M. Sobika i innych (2013).

Najczęściej badanymi elementami klimatu Tatr i Karkonoszy, zarówno w aspekcie ich aktualnego stanu, jak i zmian, są: temperatura powietrza (Hess, 1965; Głowicki, 1998, 2000; Niedźwiedź, 2004; Żmudzka, 2009; Żmudzka i inni, 2015; Migała i inni, 2016) i opady atmosferyczne (Cebulak, 1983; Niedźwiedź, 2003; Żmudzka, 2010; Ustrnul i inni, 2015). Powstały także opracowania obejmujące zmiany obydwu tych elementów klimatu (Niedźwiedź, 1992, 1996; Obrębska-Starklowa i inni, 1996; Żmudzka, 2011a, 2011b; Błażejczyk i inni, 2013). Znacznie rzadziej badane były zmiany pokrywy śnieżnej (Falarz, 2000-2001, 2002, 2007; Kozak i Łepko, 2015; Urban, 2015; Ustrnul i inni, 2015; Gądek i inni, 2016). Nieliczne są opracowania porównujące zmiany klimatu w różnych pasmach górskich Europy (Migała, 2005; Niedźwiedź, 2006).

Celem prezentowanych w tym artykule badań jest porównanie podstawowych cech klimatu (temperatury i wilgotności powietrza, opadów atmosferycznych, pokrywy śnieżnej i prędkości wiatru) i ich sezonowości oraz prześledzenie ich zmian w latach 1951-2015 w polskiej części dwóch pasm górskich: Karkonoszy i Tatr.

\section{Materiały i metoda}

Do zbadania sezonowych i wieloletnich zmian niektórych cech klimatu w Tatrach i Karkonoszach wykorzystano codzienne dane meteorologiczne pochodzące z bazy IMGW-PIB za wspólny okres 1951-2015. W przypadku Karkonoszy zgromadzono dane ze stacji na Śnieżce (Ś, 1603 m n.p.m.) oraz w Jeleniej Górze (JG, 344 m n.p.m.). Dla obszaru Tatr uwzględniono dane dla Kasprowego Wierchu (KW, 1990 m n.p.m.) i Zakopanego (Z, 857 m n.p.m.). Dobór stacji meteorologicznych uwarunkowany był dostępem do wieloletnich serii obserwacyjnych badanych elementów klimatu. Tylko dla tych czterech stacji dostępny jest w otwartej bazie IMGW-PIB komplet danych obserwacyjnych. Stacje na Śnieżce i na Kasprowym Wierchu reprezentują szczytowe części obydwu pasm górskich, natomiast stacje w Jeleniej Górze i w Zakopanem reprezentują dna obniżeń sąsiadujących z tymi pasmami. Kotlina Jeleniogórska i Obniżenie Zakopiańskie (które jest częścią Bruzdy Podtatrzańskiej, Krąż i Wójcik, 2015) różnią się wprawdzie wielkością, a stacje w nich leżące mają różne położenie w stosunku do dna kotliny (Jelenia Góra leży w najniższej części kotliny, a Zakopane - w środkowej części stożka napływowego o niewielkim nachyleniu w kierunku północnym). Niemniej, obydwie kotliny mają wyraźne zamknięcie pasmami górskimi od południa i północy oraz porównywalną odległość od stacji szczytowych (około 15 km w przypadku Jeleniej Góry i 8,5 km - Zakopanego). Dlatego też, zdaniem autora, dobrze reprezentują warunki klimatyczne panujące u północnych podnóży obydwu pasm. Dla celów porównawczych do zbioru danych włączono także dane z Hali Gąsienicowej (HG, 1520 m n.p.m.), dla której dostępne są wyniki obserwacji jedynie za lata 1981-2015. Stacja ta leży w Dolinie Suchej Wody na północnym zboczu Kasprowego Wierchu.

W opracowaniu wykorzystano dane dotyczące: temperatury powietrza (średnia dobowa, maksymalna, minimalna), wilgotności względnej powietrza, prędkości wiatru, opadów atmosferycznych oraz grubości pokrywy śnieżnej.

Obliczono średnie wieloletnie (roczne i sezonowe) wartości badanych elementów klimatu: temperatury powietrza $\left(T_{a}\right)$, temperatury maksymalnej $\left(T_{\max }\right)$, temperatury minimal- 
nej $\left(T_{\text {min }}\right)$, wilgotności względnej powietrza $(R H)$, prędkości wiatru $(v)$, sum opadów (RR) oraz maksymalnej grubości pokrywy śnieżnej $\left(\mathrm{S}_{\max }\right)$, a także liczbę dni z opadem większym lub równym 0,1 mm - RR (dni), liczbę dni z pokrywą śnieżną powyżej $0 \mathrm{~cm}-\mathrm{S}$ (dni) oraz liczbę dni charakterystycznych termicznie: gorących $\left(z T_{\max }>25^{\circ} \mathrm{C}\right)$, mroźnych $\left(T_{\max }<0^{\circ} \mathrm{C}\right)$, bardzo mroźnych $\left(T_{\min }<-10^{\circ} \mathrm{C}\right)$ i skrajnie mroźnych $\left(T_{\max }<-10^{\circ} \mathrm{C}\right)$. W przypadku $\mathrm{T}_{\max }$ i $\mathrm{T}_{\min }$ wyznaczono zarówno wieloletnie wartości średnie dla poszczególnych miesięcy i roku, jak również ich wartości absolutne w badanym okresie. Na podstawie różnicy wartości badanych elementów klimatu pomiędzy stacjami leżącymi u podnóża i w partiach szczytowych (odpowiednio pomiędzy Zakopanem a Kasprowym Wierchem w Tatrach oraz Jelenią Górą a Śnieżką w Karkonoszach, obliczono gradienty wysokościowe zmian w przeliczeniu na 100 m wysokości. Zbadano także trendy zmian analizowanych elementów klimatu w wieloleciu określając ich istotność statystyczną. Analizy statystyczne przeprowadzono z wykorzystaniem program STATGRAPHICS 7.2.

\section{Wyniki}

\section{Zmienność sezonowa podstawowych elementów klimatu}

\section{Temperatura powietrza}

Średnie wieloletnie wartości rocznej temperatury powietrza $\left(T_{a}\right)$ układają się zgodnie z wysokością danej stacji nad poziomem morza. Najniższe wartości $T_{a}$ występują na Kasprowym Wierchu $\left(-0,5^{\circ} \mathrm{C}\right.$ średnio w roku), a najwyższe w Jeleniej Górze $\left(7,6^{\circ} \mathrm{C}\right)$. Średni roczny gradient wysokościowy temperatury powietrza w obydwu pasmach jest zbliżony do siebie i wynosi $-0,53^{\circ} \mathrm{C}$ na 100 m wysokości w Tatrach i $-0,55^{\circ} \mathrm{C}-$ w Karkonoszach. Największe gradienty wysokościowe obserwowane są od kwietnia do sierpnia (od $-0,59$ do $-0,68^{\circ} \mathrm{C}$ ), a najmniejsze - w grudniu i styczniu (od $-0,34$ do $-0,37^{\circ} \mathrm{C}$ ). Zaobserwowano także pewną prawidłowość zmienności sezonowej temperatury powietrza. Zarówno u podnóża Karkonoszy, jak i u podnóża Tatr najchłodniejszym miesiącem jest styczeń, a najcieplejszym - lipiec. Na stacjach szczytowych ma miejsce miesięczne przesunięcie najniższych i najwyższych wartości $T_{a}$ i są one notowane odpowiednio w lutym i sierpniu (tab. 1).

Tabela 1. Średnie miesięczne i roczne wartości temperatury powietrza $\left(\mathrm{Ta}{ }^{\circ} \mathrm{C}\right)$ w Karkonoszach i Tatrach, 1951-2015

Mean monthly and yearly values for air temperature $\left(\mathrm{Ta}^{\circ} \mathrm{C}\right)$ in the Karkonosze and Tatra Mts., 1951-2015

\begin{tabular}{|c|c|c|c|c|c|c|c|c|c|c|c|c|c|}
\hline \multirow{2}{*}{$\begin{array}{l}\text { Stacja } \\
\text { Station }\end{array}$} & \multicolumn{12}{|c|}{ Miesiące / Months } & \multirow{2}{*}{$\begin{array}{l}\text { Rok } \\
\text { Year }\end{array}$} \\
\hline & 1 & 2 & 3 & 4 & 5 & 6 & 7 & 8 & 9 & 10 & 11 & 12 & \\
\hline$J G$ & $-2,0$ & $-1,2$ & 2,4 & 7,2 & 12,1 & 15,3 & 17,1 & 16,5 & 12,6 & 8,2 & 3,4 & $-0,5$ & 7,6 \\
\hline Ś & $-6,6$ & $-6,8$ & $-4,7$ & $-1,0$ & 3,7 & 6,9 & 8,8 & 8,8 & 5,4 & 2,1 & $-2,3$ & $-5,2$ & 0,8 \\
\hline Z & $-4,2$ & $-3,4$ & $-0,1$ & 5,1 & 10,1 & 13,2 & 14,9 & 14,4 & 10,5 & 6,2 & 1,4 & $-2,6$ & 5,5 \\
\hline KW & $-8,0$ & $-8,3$ & $-6,3$ & $-2,4$ & 2,4 & 5,7 & 7,6 & 7,7 & 4,3 & 1,2 & $-3,3$ & $-6,5$ & $-0,5$ \\
\hline $\mathrm{HG}^{*}$ & $-4,8$ & $-5,5$ & $-3,2$ & 1,3 & 6,5 & 9,3 & 11,4 & 11,4 & 7,3 & 4,0 & $-0,2$ & $-3,6$ & 2,8 \\
\hline
\end{tabular}

*dane za lata 1981-2015/data for years 1981-2015

JG - Jelenia Góra, Ś - Śnieżka, Z - Zakopane, KW - Kasprowy Wierch, HG - Hala Gąsienicowa, kolor niebieski - wartość minimalna, kolor czerwony - wartość maksymalna (tak samo pozostałe tabele)

Opracowanie własne, tak samo pozostałe tabele i ryciny/Author's own elaboration, like remaining tables and figures. 
Porównując wartości skrajne temperatury powietrza można stwierdzić, że są one, podobnie jak wartości średnie $T_{a^{\prime}}$, uwarunkowane wysokością stacji nad poziom morza. Najniższe średnie wartości $T_{\max }$ obserwowano zatem na Kasprowym Wierchu (od 2,0 $0^{\circ} \mathrm{C}$ w lutym do $18,3^{\circ} \mathrm{C}$ w lipcu), a najwyższe - w Jeleniej Górze (od $9,5^{\circ} \mathrm{C}$ w styczniu do $30,5^{\circ} \mathrm{C}$ w lipcu) (tab. 2). Zauważono także, że wyraźnie różnią się gradienty wysokościowe $T_{\max }$. W Tatrach wynoszą one $-0,77^{\circ} \mathrm{C}$, a w Karkonoszach $--0,88^{\circ} \mathrm{C}$ na $100 \mathrm{~m}$ wzniesienia.

Temperatura minimalna wyraźnie mniej niż $\mathrm{T}_{\mathrm{a}} \mathrm{i} \mathrm{T}_{\max }$ różni się pomiędzy badanymi pasmami górskimi oraz pomiędzy stacjami w każdym z pasm. Najniższe średnie wartości $T_{\min }$ notowane są na Kasprowym Wierchu (od $-20,1^{\circ} \mathrm{C}$ w styczniu do $-0,6^{\circ} \mathrm{C}$ w lipcu i sierpniu). Na Śnieżce przez cały rok temperatura minimalna powietrza jest wyraźnie wyższa niż na Kasprowym Wierchu (od $1,5^{\circ} \mathrm{C}$ w czerwcu do $3,0^{\circ} \mathrm{C}$ w lutym). Porównując temperaturę minimalną na stacjach podgórskich można zauważyć, że prawie przez cały rok Kotlina Jeleniogórska wychładza się silniej niż Bruzda Podtatrzańska w Zakopanem. Wynika to prawdopodobnie z tego, że stacja Jelenia Góra jest położona w najniższej części kotliny, a stacja Zakopane leży nie w najniższej, a w środkowej części stożka napływowego, który stopniowo obniża się ku północy (tab. 3). W Tatrach gradienty wysokościowe $T_{\min }$ przez cały rok są ujemne i wahają się od $-0,16^{\circ} \mathrm{C} / 100 \mathrm{~m}$ w styczniu i grudniu do $-0,56^{\circ} \mathrm{C} / 100 \mathrm{~m}$ w kwietniu. W Karkonoszach, w miesiącach zimowych, gradient wysokościowy ma war-

Tabela 2. Najwyższe średnie wartości temperatury maksymalnej powietrza $\left(\mathrm{T}_{\text {max }^{\prime}}{ }^{\circ} \mathrm{C}\right)$ w Karkonoszach i Tatrach, 1951-2015

Highest mean values for maximum air temperature $\left(T_{\max }{ }^{\circ} \mathrm{C}\right)$ in the Karkonosze and Tatra Mts., 1951-2015

\begin{tabular}{|l|c|r|r|r|r|r|r|r|r|r|r|r|}
\hline \multirow{2}{*}{$\begin{array}{l}\text { Stacja } \\
\text { Station }\end{array}$} & \multicolumn{10}{|c|}{ Miesiące / Months } \\
\cline { 2 - 13 } & 1 & 2 & 3 & 4 & 5 & 6 & 7 & 8 & 9 & 10 & 11 & 12 \\
\hline JG & 9,5 & 11,0 & 16,9 & 22,3 & 25,8 & 29,0 & 30,5 & 30,2 & 26,4 & 22,0 & 15,4 & 10,9 \\
Ś & 3,7 & 4,0 & 5,9 & 9,9 & 14,6 & 17,9 & 19,3 & 19,3 & 15,6 & 12,8 & 8,8 & 5,6 \\
Z & 8,9 & 9,8 & 14,0 & 18,8 & 22,9 & 25,8 & 27,5 & 27,2 & 23,8 & 20,4 & 14,9 & 10,2 \\
KW & 2,6 & 2,0 & 4,0 & 7,6 & 12,7 & 16,7 & 18,3 & 17,9 & 14,3 & 11,6 & 6,8 & 3,9 \\
HG $^{*}$ & 7,3 & 6,5 & 8,0 & 12,6 & 17,8 & 20,4 & 22,1 & 21,8 & 18,2 & 16,7 & 11,6 & 8,3 \\
\hline
\end{tabular}

*dane za lata 1981-2015, nazwy stacji - patrz tabela 1

data for years 1981-2015, for names of stations - see Table 1

Tabela 3. Najniższe średnie wartości temperatury minimalnej powietrza $\left(\mathrm{T}_{\min }{ }^{\circ} \mathrm{C}\right) \mathrm{w}$ Karkonoszach i Tatrach, 1951-2015

Lowest mean values for minimum air temperature $\left(T_{\text {min' }^{\prime}}{ }^{\circ} \mathrm{C}\right)$ in Karkonosze and Tatra Mts., 1951-2015

\begin{tabular}{|l|c|c|c|c|c|c|c|c|c|c|c|c|}
\hline \multirow{2}{*}{$\begin{array}{c}\text { Stacja } \\
\text { Station }\end{array}$} & \multicolumn{10}{|c|}{ Miesiące / Months } \\
\cline { 2 - 12 } & 1 & 2 & 3 & 4 & 5 & 6 & 7 & 8 & 9 & 10 & 11 & 12 \\
\hline JG & $-20,2$ & $-17,2$ & $-11,7$ & $-6,0$ & $-1,6$ & 2,0 & 4,7 & 3,6 & $-0,4$ & $-5,1$ & $-9,9$ & $-16,9$ \\
Ś & $-17,5$ & $-16,6$ & $-14,5$ & $-10,9$ & $-5,8$ & $-1,8$ & 0,9 & 1,0 & $-2,5$ & $-7,0$ & $-11,8$ & $-15,5$ \\
Z & $-18,8$ & $-17,6$ & $-13,6$ & $-6,7$ & $-1,4$ & 2,6 & 4,8 & 3,9 & $-0,4$ & $-5,4$ & $-11,1$ & $-16,7$ \\
KW & $-20,1$ & $-19,6$ & $-17,3$ & $-13,0$ & $-7,4$ & $-3,1$ & $-0,7$ & $-0,6$ & $-4,8$ & $-9,6$ & $-14,4$ & $-18,2$ \\
HG & $-18,4$ & $-18,8$ & $-15,4$ & $-10,7$ & $-4,1$ & 0,0 & 1,9 & 1,7 & $-1,7$ & $-8,0$ & $-12,3$ & $-17,2$ \\
\hline
\end{tabular}

*dane za lata 1981-2015, nazwy stacji - patrz tabela 1

data for years 1981-2015, for names of stations - see Table 1 
tość dodatnią $\left(0,09-0,24^{\circ} \mathrm{C} / 100 \mathrm{~m}\right)$, a w pozostałych miesiącach jest ujemny, osiągając $-0,37^{\circ} \mathrm{C} / 100 \mathrm{~m}$ w kwietniu.

W sposób zróżnicowany kształtuje się rozkład dni charakterystycznych termicznie. Dni gorące $\left(z \mathrm{~T}_{\max }>25^{\circ} \mathrm{C}\right)$ obserwowane są praktycznie tylko w kotlinach u podnóża badanych pasm górskich. Na stacjach szczytowych nie są notowane, a na stacji zboczowej w Tatrach (Hala Gąsienicowa) występują sporadycznie w miesiącach letnich (tab. 4). Liczba dni mroźnych w roku $\left(z \mathrm{~T}_{\max }<0^{\circ} \mathrm{C}\right)$ waha się od około 32 w Jeleniej Górze do prawie 145 na Kasprowym Wierchu. Średnio w roku na każde 100 m wysokości liczba dni mroźnych zwiększa się w Karkonoszach o 7,58 dnia, a w Tatrach o 8,24 dnia. U podnóża Karkonoszy dni

Tabela 4. Średnie miesięczne i roczne liczby dni w charakterystycznymi wartościami temperatury powietrza w Karkonoszach i Tatrach, 1951-2015

Mean monthly and yearly numbers of days with specific air-temperature values in the Karkonosze and Tatra Mts., 1951-2015

\begin{tabular}{|c|c|c|c|c|c|c|c|c|c|c|c|c|c|}
\hline \multirow{2}{*}{$\begin{array}{l}\text { Stacja } \\
\text { Station }\end{array}$} & \multicolumn{12}{|c|}{ Miesiące / Months } & \multirow{2}{*}{$\begin{array}{l}\text { Rok } \\
\text { Year }\end{array}$} \\
\hline & 1 & 2 & 3 & 4 & 5 & 6 & 7 & 8 & 9 & 10 & 11 & 12 & \\
\hline \multicolumn{14}{|c|}{$\mathrm{T}_{\text {max }}>25^{\circ} \mathrm{C}$} \\
\hline$J G$ & - & - & - & 0,4 & 2,2 & 5,7 & 10,0 & 9,4 & 2,1 & 0,1 & - & - & 29,9 \\
\hline Ś & - & - & - & - & - & - & - & - & - & - & - & - & - \\
\hline Z & - & - & - & - & 0,4 & 2,0 & 4,1 & 4,1 & 0,4 & - & - & - & 11,1 \\
\hline KW & - & - & - & - & - & - & - & - & - & - & - & - & - \\
\hline $\mathrm{HG}^{*}$ & - & - & - & - & - & 0,1 & 0,1 & 0,1 & - & - & - & - & 0,3 \\
\hline \multicolumn{14}{|c|}{$\mathrm{T}_{\max }<0^{\circ} \mathrm{C}$} \\
\hline$J G$ & 10,5 & 8,2 & 3,3 & 0,1 & - & - & - & - & - & - & 1,8 & 7,8 & 31,6 \\
\hline Ś & 24,9 & 22,8 & 20,9 & 11,8 & 2,7 & 0,1 & - & - & 0,8 & 6,2 & 15,1 & 22,0 & 127,2 \\
\hline Z & 14,3 & 11,6 & 6,5 & 1,0 & - & - & - & - & - & 0,3 & 4,8 & 12,4 & 50,7 \\
\hline KW & 27,2 & 25,0 & 23,9 & 14,2 & 4,2 & 0,8 & 0,0 & 0,1 & 2,4 & 7,0 & 15,7 & 24,2 & 144,6 \\
\hline $\mathrm{HG}^{*}$ & 17,0 & 16,5 & 13,5 & 5,1 & 0,4 & - & - & - & 0,1 & 2,7 & 8,5 & 14,9 & 78,8 \\
\hline \multicolumn{14}{|c|}{$\mathrm{T}_{\min }<-10^{\circ} \mathrm{C}$} \\
\hline$J G$ & 7,5 & 5,7 & 1,9 & 0,1 & - & - & - & - & - & - & 0,9 & 5,0 & 21,0 \\
\hline Ś & 11,9 & 11,9 & 8,3 & 2,0 & - & - & - & - & - & 0,3 & 3,6 & 9,1 & 47,0 \\
\hline Z & 11,5 & 8,5 & 4,8 & 0,1 & - & - & - & - & - & 0,1 & 2,1 & 7,8 & 34,8 \\
\hline KW & 16,6 & 15,6 & 12,4 & 4,4 & 0,3 & - & - & - & - & 1,1 & 6,6 & 13,3 & 70,4 \\
\hline $\mathrm{HG}^{*}$ & 10,4 & 11,3 & 7,5 & 1,7 & - & - & - & - & - & 0,6 & 3,9 & 9,1 & 44,5 \\
\hline \multicolumn{14}{|c|}{$\mathrm{T}_{\max }<-10^{\circ} \mathrm{C}$} \\
\hline$J G$ & 0,7 & 0,3 & - & - & - & - & - & - & - & - & - & 0,2 & 1,3 \\
\hline Ś & 3,4 & 4,0 & 1,9 & 0,1 & - & - & - & - & - & - & 0,4 & 2,0 & 11,8 \\
\hline Z & 1,1 & 0,8 & 0,1 & - & - & - & - & - & - & - & - & 0,4 & 2,4 \\
\hline KW & 5,2 & 5,3 & 2,9 & 0,2 & - & - & - & - & - & 0,1 & 1,2 & 3,4 & 18,3 \\
\hline $\mathrm{HG}^{*}$ & 1,9 & 2,0 & 0,9 & - & - & - & - & - & - & - & 0,2 & 1,2 & 6,3 \\
\hline
\end{tabular}

*dane za lata 1981-2015, - zjawisko nie występuje, nazwy stacji - patrz tabela 1

data for years 1981-2015, - phenomenon does not exist, for names of stations - see Table 1 
mroźne są notowane od listopada do kwietnia, a w Obniżeniu Zakopiańskim - od października do kwietnia. Na stacjach szczytowych mogą się one pojawiać przez większość roku (poza lipcem i sierpniem w Karkonoszach). Dni bardzo mroźnych $\left(z \mathrm{~T}_{\min }<-10^{\circ} \mathrm{C}\right)$ jest w roku od 21 w Jeleniej Górze do 70 na Kasprowym Wierchu. Porównując Tatry i Karkonosze można także zauważyć, że roczna liczba dni bardzo mroźnych na Hali Gąsienicowej $(44,5)$ i na Śnieżce $(47,0)$ jest zbliżona do siebie, mimo różnego położenia obu stacji (przy podobnej wysokości nad poziom morza, pierwsza ze stacji leży w górnej części Doliny Suchej Wody, a druga - na szczycie Śnieżki). Okres, w którym występują dni skrajnie mroźne, w Kotlinie Jeleniogórskiej obejmuje miesiące od grudnia do lutego, a w Obniżeniu Zakopiańskim - od grudnia do marca. Najdłużej (od października do kwietnia) okres z dniami skrajnie mroźnymi trwa na Kasprowym Wierchu (tab. 4).

\section{Opady}

Roczne sumy opadów są w Karkonoszach wyraźnie niższe niż w Tatrach. Na Śnieżce spada średnio około 1212 mm opadów w roku, niewiele więcej niż u podnóża Tatr w Zakopanem (1128 mm). W wyższych partiach Tatr spada rocznie około 1700 mm opadów (1650 mm)

Tabela 5. Średnie miesięczne i roczne charakterystyki opadów atmosferycznych w Karkonoszach i Tatrach, 1951-2015

Mean monthly and yearly values for precipitation characteristics in the Karkonosze and Tatra Mts., 1951-2015

\begin{tabular}{|c|c|c|c|c|c|c|c|c|c|c|c|c|c|}
\hline \multirow{2}{*}{$\begin{array}{l}\text { Stacja } \\
\text { Station }\end{array}$} & \multicolumn{12}{|c|}{ Miesiące / Months } & \multirow{2}{*}{$\begin{array}{l}\text { Rok } \\
\text { Year }\end{array}$} \\
\hline & 1 & 2 & 3 & 4 & 5 & 6 & 7 & 8 & 9 & 10 & 11 & 12 & \\
\hline \multicolumn{14}{|c|}{ sumy opadu $(\mathrm{mm}) /$ precipitation totals $(\mathrm{mm})$} \\
\hline JG & 34,4 & 31,2 & 39,4 & 48,9 & 76,8 & 85,0 & 103,7 & 81,0 & 57,1 & 43,3 & 42,3 & 36,4 & 679,7 \\
\hline Ś & 96,2 & 93,6 & 89,2 & 86,6 & 101,7 & 123,2 & 142,7 & 115,3 & 86,9 & 77,1 & 96,4 & 102,5 & 1211,6 \\
\hline Z & 47,7 & 46,0 & 57,9 & 79,6 & 130,2 & 169,3 & 179,3 & 136,6 & 97,9 & 70,7 & 61,4 & 51,4 & 1127,9 \\
\hline KW & 112,7 & 108,7 & 114,1 & 132,3 & 172,1 & 212,1 & 217,1 & 173,5 & 133,0 & 106,0 & 117,9 & 119,8 & 1720,6 \\
\hline $\mathrm{HG}^{*}$ & 73,3 & 63,9 & 86,4 & 110,6 & 206,3 & 233,3 & 258,2 & 196,6 & 171,4 & 113,6 & 103,2 & 78,1 & 1694,9 \\
\hline \multicolumn{14}{|c|}{ liczba dni z opadem >0,1 mm / number of days with precipitation $>0.1 \mathrm{~mm}$} \\
\hline JG & 15,8 & 14,8 & 15,3 & 13,5 & 15,3 & 15,8 & 15,2 & 13,4 & 13,1 & 12,9 & 15,1 & 16,2 & 176,4 \\
\hline Ś & 22,0 & 19,8 & 21,0 & 18,4 & 18,7 & 18,8 & 18,7 & 16,9 & 18,1 & 18,9 & 21,6 & 22,4 & 235,2 \\
\hline Z & 16,9 & 15,5 & 16,5 & 16,4 & 18,7 & 18,8 & 18,1 & 15,7 & 14,2 & 13,5 & 15,8 & 16,9 & 197,1 \\
\hline $\mathrm{KW}$ & 20,1 & 18,8 & 20,3 & 19,5 & 20,7 & 20,8 & 19,4 & 17,4 & 16,0 & 15,6 & 18,2 & 20,5 & 227,3 \\
\hline $\mathrm{HG}^{*}$ & 19,5 & 18,1 & 19,8 & 18,7 & 20,1 & 20,5 & 18,9 & 16,0 & 15,1 & 15,5 & 17,2 & 19,9 & 219,3 \\
\hline \multicolumn{14}{|c|}{ liczba dni z opadem >10 mm / number of days with precipitation $>10 \mathrm{~mm}$} \\
\hline$J G$ & 0,4 & 0,2 & 0,5 & 1,1 & 2,2 & 2,6 & 2,9 & 2,3 & 1,6 & 1,0 & 0,8 & 0,5 & 16,3 \\
\hline Ś & 2,4 & 2,7 & 2,3 & 2,2 & 2,8 & 3,7 & 4,3 & 3,2 & 2,4 & 2,0 & 2,5 & 2,7 & 33,2 \\
\hline Z & 1,0 & 0,9 & 1,2 & 2,3 & 4,2 & 5,5 & 5,7 & 4,4 & 3,2 & 2,3 & 1,5 & 1,0 & 33,2 \\
\hline KW & 3,4 & 3,3 & 3,6 & 4,0 & 5,4 & 6,5 & 6,5 & 5,4 & 4,3 & 3,6 & 3,7 & 3,7 & 53,5 \\
\hline $\mathrm{HG}^{*}$ & 2,0 & 1,7 & 2,2 & 3,6 & 6,3 & 7,4 & 7,9 & 5,8 & 5,5 & 3,5 & 3,3 & 2,0 & 51,2 \\
\hline
\end{tabular}

*dane za lata 1981-2015, nazwy stacji - patrz tabela 1

data for years 1981-2015, for names of stations - see Table 1 
na Hali Gąsienicowej i 1721 mm na Kasprowym Wierchu). Stosunkowo małe sumy opadów na Śnieżce można wiązać zarówno z czynnikami cyrkulacyjnymi i orientacją grzbietu w stosunku do deszczonośnych mas powietrza, jak również z dużymi prędkościami wiatru, które mogą zniekształcać wskazania deszczomierza. Także gradient wysokościowy sum opadów jest w Karkonoszach wyraźnie niższy niż w Tatrach (odpowiednio, 38,0 i 52,9 mm na 100 m wzniesienia). W obydwu pasmach górskich najbardziej obfity w opady jest lipiec (od 104 mm w Jeleniej Górze do 258 mm na Hali Gąsienicowej). Przy stosunkowo małych sumach na Śnieżce notuje się więcej dni z opadem (około 235 rocznie) niż na Kasprowym Wierchu (227). W Karkonoszach na każde 100 m wzniesienia roczna liczba dni z opadem zwiększa się o 4,7, natomiast w Tatrach - jedynie o 2,5. W Karkonoszach najwięcej dni z opadem występuje w grudniu, natomiast w Tatrach - w czerwcu. Dla odmiany, w Tatrach notuje się znacznie więcej dni z dużym opadem (>10 mm) niż w Karkonoszach: 54 dni rocznie na Kasprowym Wierchu i 33 - na Śnieżce. Odpowiednie gradienty wysokościowe wynoszą 1,8 i 1,2 dnia na 100 m wzniesienia. Najwięcej dni z intensywnym opadem (>10 mm na dobę) w obydwu pasmach notuje się w lipcu (tab. 5).

\section{Wilgotność względna}

Wilgotność względna powietrza jest stosunkowo mało zróżnicowana, zarówno pomiędzy badanymi pasmami, jak i w przebiegu rocznym. W kotlinach podgórskich najwyższe wartości wilgotności względnej powietrza występują w miesiącach jesiennych i zimowych. W wyżej wyniesionych partiach Karkonoszy i Tatr okres letni cechuje się zwiększoną, a okres zimowy - zmniejszoną wilgotnością powietrza (tab. 6). Jest to prawdopodobnie związane z zaleganiem w tym czasie zwartej pokrywy śnieżnej oraz z inwersją termiczną z osiadania obejmującą górne partie Tatr i Karkonoszy. Latem natomiast podwyższona wilgotność jest efektem przewagi ruchów wstępujących, które prowadzą do adiabatycznego ochładzania powietrza, a w konsekwencji do obfitych i częstych opadów deszczu.

Tabela 6. Średnie miesięczne i roczne wartości wilgotności względnej powietrza (RH,\%) w Karkonoszach i Tatrach, 1951-2015

Mean monthly and yearly values for relative air humidity (RH, \%) in the Karkonosze and Tatra Mts., 1951-2015

\begin{tabular}{|l|c|c|c|c|c|c|c|c|c|c|c|c|c|}
\hline \multirow{2}{*}{$\begin{array}{c}\text { Stacja } \\
\text { Station }\end{array}$} & \multicolumn{10}{|c|}{ Miesiące / Months } & $\begin{array}{c}\text { Rok } \\
\text { Year }\end{array}$ \\
\cline { 2 - 14 } & 1 & 2 & 3 & 4 & 5 & 6 & 7 & 8 & 9 & 10 & 11 & 12 & Jear \\
\hline JG & 83,1 & 81,3 & 76,4 & 72,8 & 74,0 & 75,3 & 75,5 & 77,1 & 80,1 & 81,7 & 84,4 & 84,7 & 78,9 \\
Ś & 84,4 & 84,9 & 86,9 & 87,7 & 87,7 & 88,5 & 87,9 & 87,6 & 89,6 & 85,1 & 86,2 & 84,6 & 86,7 \\
Z & 81,4 & 79,3 & 76,2 & 73,6 & 75,0 & 77,7 & 78,0 & 79,4 & 81,8 & 81,3 & 82,7 & 83,2 & 79,1 \\
KW & 77,3 & 78,6 & 81,1 & 85,0 & 86,8 & 88,3 & 87,3 & 85,8 & 85,0 & 77,7 & 81,0 & 78,7 & 82,7 \\
HG $^{*}$ & 72,2 & 73,7 & 74,9 & 75,1 & 76,6 & 80,1 & 79,4 & 78,5 & 80,7 & 75,0 & 75,6 & 72,7 & 76,2 \\
\hline
\end{tabular}

*dane za lata 1981-2015, nazwy stacji - patrz tabela 1

data for years 1981-2015, for names of stations - see Table 1

\section{Pokrywa śnieżna}

Pokrywa śnieżna w wysokich partiach Tatr zalega średnio przez 218 dni w roku, przy czym obserwowana jest w każdym miesiącu. Od grudnia do marca jest tam notowana praktycz- 
nie każdego dnia. Na Śnieżce dni z pokrywą śnieżną jest zdecydowanie mniej (184 rocznie) niż na KW, a luty jest jedynym miesiącem, w którym występuje każdego dnia. W sierpniu na Śnieżce pokrywa śnieżna nie jest notowana. W Kotlinie Jeleniogórskiej jej występowanie ogranicza się do okresu od października do kwietnia (64 dni w roku), a u podnóża Tatr - od października do maja (124 dni w roku) (tab. 7).

Tabela 7. Średnie miesięczne i roczne liczby dni z pokrywą śnieżną w Karkonoszach i Tatrach, 1951-2015. Mean monthly and yearly values for numbers of days with snow cover in the Karkonosze and Tatra Mts., 1951-2015

\begin{tabular}{|c|c|c|c|c|c|c|c|c|c|c|c|c|c|}
\hline \multirow{2}{*}{$\begin{array}{l}\text { Stacja } \\
\text { Station }\end{array}$} & \multicolumn{12}{|c|}{ Miesiące / Months } & \multirow{2}{*}{$\begin{array}{l}\text { Rok } \\
\text { Year }\end{array}$} \\
\hline & 1 & 2 & 3 & 4 & 5 & 6 & 7 & 8 & 9 & 10 & 11 & 12 & \\
\hline JG & 18,4 & 15,7 & 9,0 & 2,1 & 0,1 & - & - & - & - & 0,3 & 5,3 & 13,8 & 63,2 \\
\hline Ś & 30,4 & 28,0 & 30,0 & 27,6 & 11,0 & 0,8 & 0,0 & - & 1,3 & 7,9 & 19,4 & 28,5 & 183,6 \\
\hline Z & 28,1 & 25,8 & 22,4 & 7,4 & 0,7 & 0,1 & - & - & - & 2,6 & 11,9 & 24,0 & 126,2 \\
\hline KW & 31,0 & 28,2 & 31,0 & 29,9 & 21,1 & 4,2 & 0,7 & 0,7 & 5,5 & 12,7 & 23,9 & 30,8 & 218,1 \\
\hline $\mathrm{HG}^{*}$ & 27,4 & 26,6 & 28,9 & 24,2 & 5,8 & 0,9 & 0,1 & - & 2,0 & 8,0 & 17,2 & 26,3 & 175,3 \\
\hline
\end{tabular}

*dane za lata 1981-2015, - zjawisko nie występuje, nazwy stacji - patrz tabela 1

data for years 1981-2015, - phenomenon does not exist, for names of stations - see Table 1

Grubość pokrywy śnieżnej w Tatrach jest większa niż w Karkonoszach. Przyczyn tych różnic można upatrywać, podobnie jak w przypadku opadów, zarówno w czynnikach cyrkulacyjnych, jak i w dużej prędkości wiatru, która sprzyja wywiewaniu śniegu z partii szczytowych. W miesiącach zimowych i wiosennych pokrywa śnieżna waha się odpowiednio od średnio $58 \mathrm{~cm}$ (grudzień) do $180 \mathrm{~cm}$ (marzec-kwiecień) na Kasprowym Wierchu i od $41 \mathrm{~cm}$ (grudzień) do $137 \mathrm{~cm}$ (marzec) cm na Śnieżce. W obydwu pasmach grubość pokrywy śnieżnej w miesiącach wiosennych jest większa niż w zimowych. Należy także pokreślić, że średnie maksymalne grubości pokrywy śnieżnej na Śnieżce są podobne do tych obserwowanych na Hali Gąsienicowej (48-135 cm) (tab. 8).

Tabela 8. Średnie miesięczne grubości maksymalnej pokrywy śnieżnej ( $\mathrm{S}_{\max } \mathrm{cm}$ ) w Karkonoszach i Tatrach, 1951-2015

Mean monthly maximum depths of snow cover $(\mathrm{cm})$ in the Karkonosze and Tatra Mts., 1951-2015

\begin{tabular}{|c|c|c|c|c|c|c|c|c|c|c|c|c|}
\hline \multirow{2}{*}{$\begin{array}{l}\text { Stacja } \\
\text { Station }\end{array}$} & \multicolumn{12}{|c|}{ Miesiące / Months } \\
\hline & 1 & 2 & 3 & 4 & 5 & 6 & 7 & 8 & 9 & 10 & 11 & 12 \\
\hline JG & 17,6 & 17,9 & 13,2 & 4,4 & 0,5 & - & - & - & - & 0,7 & 8,0 & 13,1 \\
\hline Ś & 101,5 & 126,4 & 137,1 & 112,8 & 47,1 & 2,4 & 0,0 & 0,0 & 3,1 & 15,0 & 41,1 & 73,2 \\
\hline Z & 44,0 & 50,8 & 43,9 & 20,5 & 2,4 & 0,2 & - & - & - & 6,5 & 22,3 & 33,2 \\
\hline KW & 127,2 & 156,8 & 179,8 & 179,8 & 117,1 & 25,8 & 2,2 & 2,4 & 14,9 & 27,2 & 57,8 & 96,4 \\
\hline $\mathrm{HG}^{*}$ & 97,7 & 128,4 & 134,7 & 116,4 & 34,7 & 4,9 & 0,3 & 0,1 & 8,9 & 23,7 & 47,9 & 73,4 \\
\hline
\end{tabular}

*dane za lata 1981-2015, - zjawisko nie występuje, nazwy stacji - patrz tabela 1 data for years 1981-2015, - phenomenon does not exist, for names of stations - see Table 1 


\section{Prędkość wiatru}

Prędkość wiatru w partiach szczytowych Tatr i Karkonoszy jest wyraźnie większa niż na stacjach leżących u ich podnóża i na ich zboczach, przy czym okres jesienno-zimowy jest bardziej wietrzny od letniego. Należy przy tym dodać, że na Śnieżce prędkość wiatru jest prawie dwukrotnie większa niż na Kasprowym Wierchu, mimo większej wysokości tego drugiego szczytu. Także dno Kotliny Jeleniogórskiej jest bardziej wietrzne niż dno Obniżenia Zakopiańskiego (tab. 9).

Tabela 9. Średnie miesięczne i roczne prędkości wiatru (v, m/s) w Karkonoszach i Tatrach, 1951-2015 Mean monthly and yearly values for wind speed $(v, m / s)$ in the Karkonosze and Tatra Mts., 1951-2015

\begin{tabular}{|l|r|r|r|r|r|r|r|r|r|r|r|r|r|}
\hline \multirow{2}{*}{$\begin{array}{l}\text { Stacja } \\
\text { Station }\end{array}$} & \multicolumn{10}{|c|}{ Miesiące / Months } & \multicolumn{1}{c|}{$\begin{array}{c}\text { Rok } \\
\text { Year }\end{array}$} \\
\cline { 2 - 13 } & 1 & 2 & 3 & 4 & 5 & 6 & 7 & 8 & 9 & 10 & 11 & 12 & \multicolumn{1}{c|}{ Year } \\
\hline JG & 2,9 & 2,8 & 3,0 & 2,6 & 2,3 & 2,1 & 2,0 & 1,8 & 2,1 & 2,4 & 2,7 & 2,8 & 2,5 \\
Ś & 15,6 & 14,7 & 13,9 & 11,4 & 9,8 & 9,4 & 9,7 & 9,2 & 11,0 & 12,3 & 14,1 & 15,2 & 12,2 \\
Z & 1,5 & 1,5 & 1,7 & 1,6 & 1,5 & 1,3 & 1,2 & 1,1 & 1,2 & 1,3 & 1,5 & 1,5 & 1,4 \\
KW & 8,1 & 7,8 & 7,2 & 6,4 & 5,7 & 5,2 & 5,2 & 5,0 & 5,9 & 6,9 & 8,0 & 8,1 & 6,6 \\
HG $^{*}$ & 3,7 & 3,5 & 3,5 & 3,1 & 2,6 & 2,1 & 2,1 & 2,2 & 2,7 & 3,4 & 3,8 & 3,8 & 3,0 \\
\hline
\end{tabular}

*dane za lata 1981-2015, nazwy stacji - patrz tabela 1

data for years 1981-2015, for names of stations - see Table 1

\section{Wieloletnie zmiany klimatu}

W badanym okresie 1951-2015 na wszystkich stacjach, zarówno w Tatrach, jak i w Sudetach, obserwuje się wyraźny trend wzrostowy średniej rocznej temperatury powietrza. Jednak w czasie 30 pierwszych lat wielolecia zmiany $T_{a}$ były nieznaczne, a na niektórych stacjach występował nawet niewielki trend spadkowy. Wyraźne wzrosty temperatury mają natomiast miejsce po 1980 r. (ryc. 1).

Podobny do $T_{a}$ rytm zmienności wieloletniej obserwuje się w przypadku temperatury maksymalnej powietrza. Wartości $T_{\max }$ obserwowane na stacjach podgórskich (Zakopane,

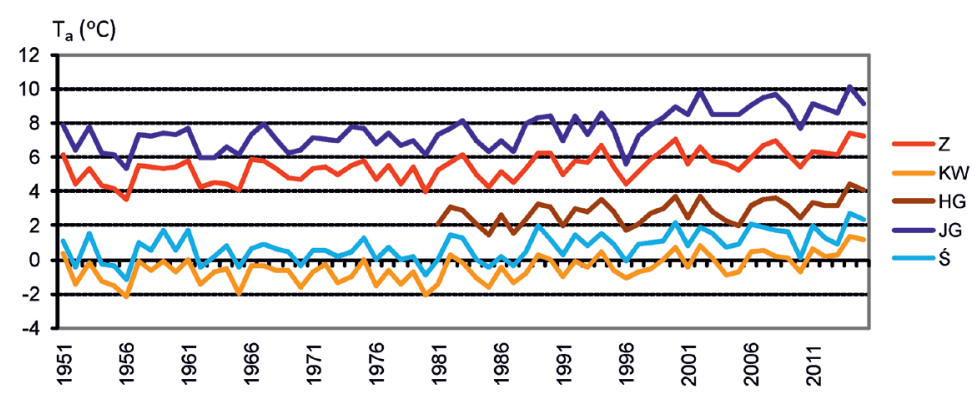

Ryc. 1. Średnie roczne wartości temperatury powietrza $\left(T_{a}\right)$ na badanych stacjach w Tatrach i Karkonoszach, 1951-2015

Mean annual air temperature $\left(T_{a}\right)$ at studied stations in the Tatra and Karkonosze Mts., 1951-2015 Nazwy stacji - patrz tabela 1 / For names of stations - see Table 1 
Jelenia Góra) są wyraźnie wyższe od temperatury notowanej w wyższych partiach gór. Natomiast $T_{\max }$ na Śnieżce, Kasprowym Wierchu i Hali Gąsienicowej są zbliżone do siebie i cechują się podobnymi do siebie zmianami wieloletnimi (ryc. 2).

Odmiennie kształtują się dane dotyczące temperatury minimalnej. Wartości $T_{\min }$ nie różnią się znacząco pomiędzy stacjami, a w badanym wieloleciu wyraźnie zaznaczają się lata 1985-1987, kiedy obserwowano najniższe temperatury minimalne (ryc. 3).

W przypadku rocznych sum opadów atmosferycznych brak jest wyraźnej tendencji zmian. Wyjątkiem jest Śnieżka, na której obserwuje się nieznaczny trend malejący RR. Znamienne jest także, że roczne sumy opadów w Zakopanem i na Śnieżce mają przez cały badany okres zbliżone do siebie wartości, mimo znacznej różnicy położenia stacji (wysokość nad poziom morza, lokalizacja topograficzna) (ryc. 4).

Ogólny obraz zmian dni z opadem atmosferycznym wskazuje na stopniowe zmniejszanie się liczby dni deszczowych i śnieżnych. Niemniej, w tym ogólnym trendzie malejącym wyróżniają się lata 1991-2000, gdy liczba dni z opadem wyraźnie wzrosła, zwłaszcza na stacjach karkonoskich (ryc. 5).

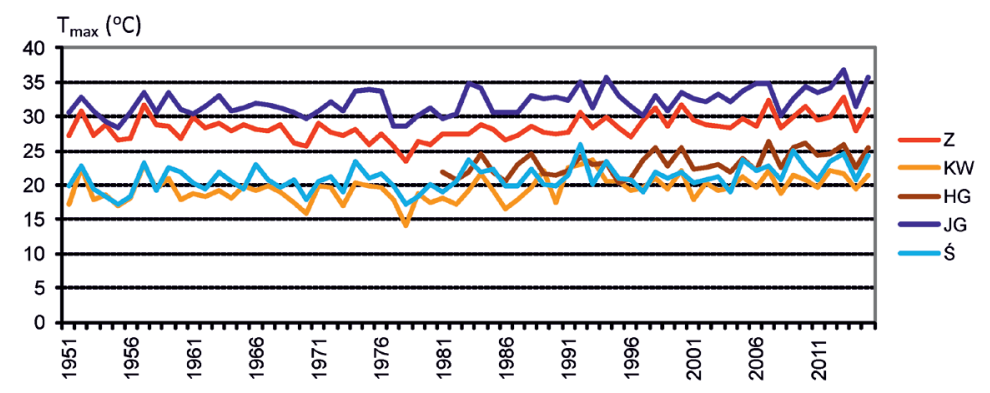

Ryc. 2. Najwyższe wartości temperatury maksymalnej powietrza $\left(T_{\max }\right)$ na badanych stacjach w Tatrach i Karkonoszach, 1951-2015

Highest annual maximum air temperatures ( $\left.T_{\max }\right)$ at studied stations in the Tatra and Karkonosze Mts., 1951-2015

Nazwy stacji - patrz tabela 1 / For names of stations - see Table 1

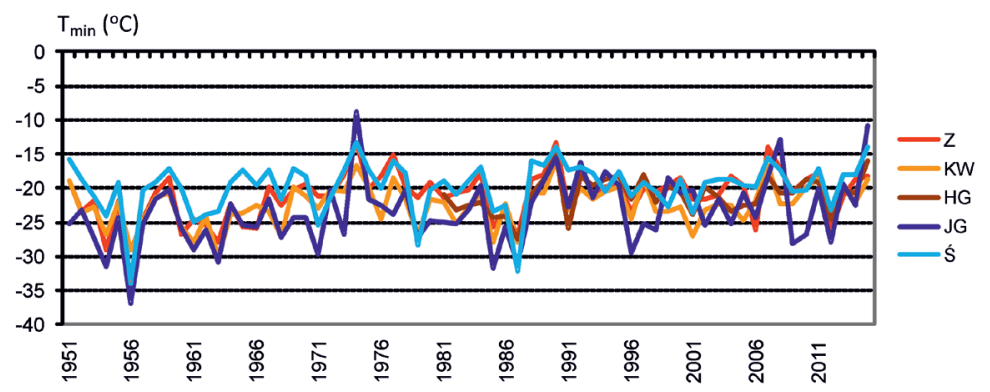

Ryc. 3. Najniższe wartości temperatury minimalnej powietrza $\left(T_{\min }\right)$ na badanych stacjach w Tatrach i Karkonoszach, 1951-2015

Lowest annual minimum air temperatures $\left(T_{\min }\right)$ at studied stations in the Tatra and Karkonosze Mts., 1951-2015

Nazwy stacji - patrz tabela 1 / For names of stations - see Table 1 


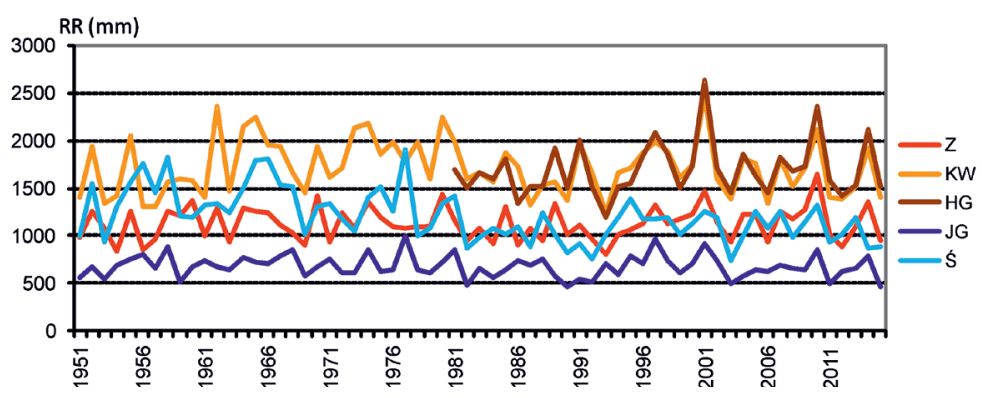

Ryc. 4. Średnie roczne sumy opadów atmosferycznych (RR) na badanych stacjach w Tatrach i Karkonoszach, 1951-2015

Mean annual totals for precipitation (RR) at studied stations in the Tatra and Karkonosze Mts., 1951-2015 Nazwy stacji - patrz tabela 1 / For names of stations - see Table 1

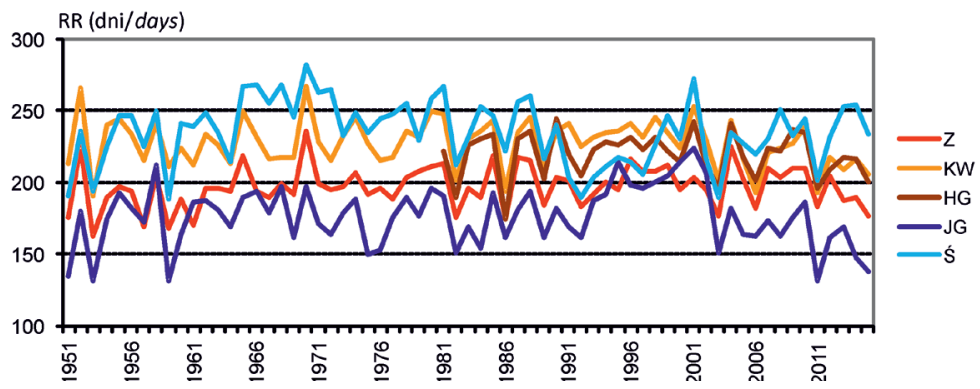

Ryc. 5. Średnia roczna liczba dni z opadem - RR (dni) - na badanych stacjach w Tatrach i Karkonoszach, 1951-2015

Mean annual number of days with precipitation - RR (days) - at studied stations in the Tatra and Karkonosze Mts., 1951-2015

Nazwy stacji - patrz tabela 1 / For names of stations - see Table 1

Wilgotność względna powietrza nieznacznie się zmniejszała w badanym wieloleciu, przede wszystkim na stacjach karkonoskich. W Tatrach, na Kasprowym Wierchu i w Zakopanem zmiany RH nie są widoczne. Natomiast na Hali Gąsienicowej, po roku 1992, zaznacza się trend wzrostowy RH (ryc. 6).

Spośród badanych elementów klimatu prędkość wiatru podlegała najmniejszym zmianom z roku na rok oraz w całym wieloleciu. Skokowa zmiana prędkości wiatru wystąpiła na przełomie roku 2009 i 2010 na Śnieżce. Było to jednak spowodowane zmianą lokalizacji i typu wiatromierza po katastrofie budowlanej w Obserwatorium, a nie zmianą warunków wiatrowych (ryc. 7).

Na obszarach górskich ważną rolę odgrywa pokrywa śnieżna. W okresie 1951-2015 nie obserwowano znaczących zmian tego elementu klimatu. Jedynie na Śnieżce i w Zakopanem można obserwować stopniowy spadek liczby dni z pokrywą śnieżną. Na pozostałych stacjach mamy do czynienia z fluktuacjami tej cechy klimatu. O ile w przypadku Kasprowego Wierchu i Hali Gąsienicowej wahania te były niewielkie, to w Jeleniej Górze liczba dni z pokrywą śnieżną zmieniała się wyraźnie pomiędzy kolejnymi latami (ryc. 8). 


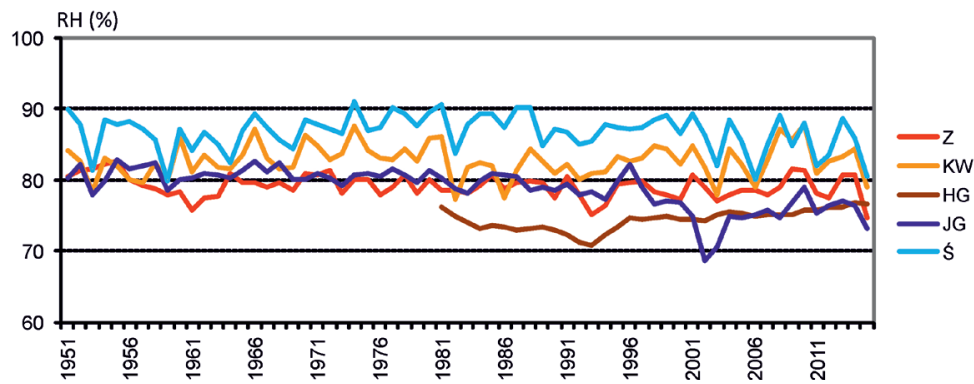

Ryc. 6. Średnie roczne wartości wilgotności względnej powietrza $(\mathrm{RH})$ na badanych stacjach w Tatrach i Karkonoszach, 1951-2015

Mean annual relative humidity of the air (RH) at studied stations in the Tatra and Karkonosze Mts., 1951-2015 Nazwy stacji - patrz tabela 1 / For names of stations - see Table 1

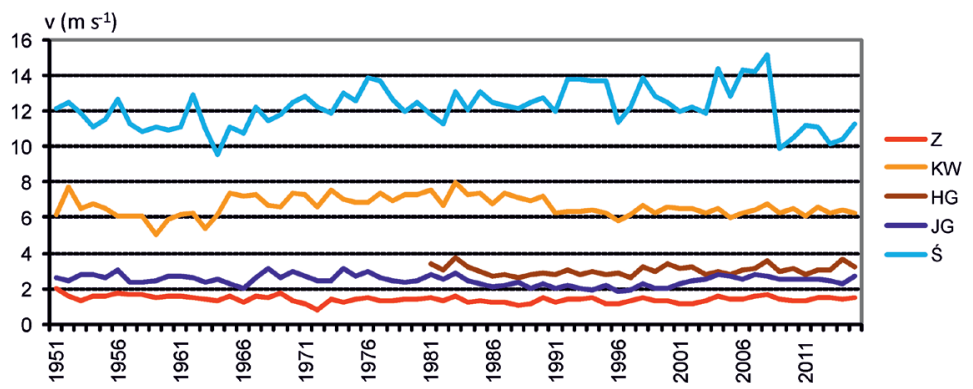

Ryc. 7. Średnie roczne prędkości wiatru (v) na badanych stacjach w Tatrach i Karkonoszach, 1951-2015 Mean annual wind speed (v) at studied stations in the Tatra and Karkonosze Mts., 1951-2015 Nazwy stacji - patrz tabela 1 / For names of stations - see Table 1

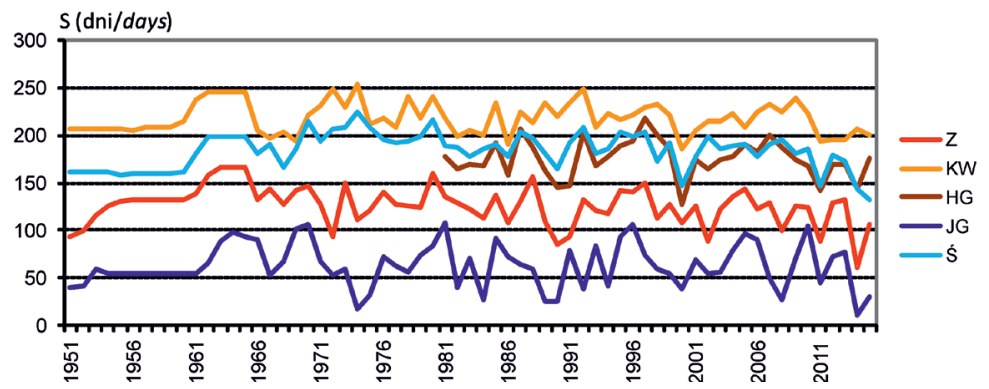

Ryc. 8. Średnia roczna liczba dni z pokrywą śnieżną - S (dni) - na badanych stacjach w Tatrach i Karkonoszach, 1951-2015

Mean annual number of days with snow cover - S (days) - at studied stations in the Tatra and Karkonosze Mts., 1951-2015

Nazwy stacji - patrz tabela 1 / For names of stations - see Table 1 
Ciekawie wygląda wieloletnia zmienność maksymalnej grubości pokrywy śnieżnej. Na stacjach leżących w dnach kotlin przedgórskich $\mathrm{S}_{\max }$ w kolejnych latach zmieniała się nieznacznie. W wysokich partiach gór zmiany $S_{\max }$ były bardzo duże. Na przykład, na Kasprowym Wierchu maksymalna grubość pokrywy śnieżnej wahała się od około $100 \mathrm{~cm}$ w latach 1984, 1990 i 2011 do około 300 cm w latach 1952-1967 oraz 1995-2000 i 2009. Na Śnieżce wahania te nie były aż tak duże jak na KW i mieściły się w zakresie od około $50 \mathrm{~cm}(1972$ i 2014) do $250 \mathrm{~cm}(1988,2005)$ (ryc. 9).

Kolejnym etapem badań było sprawdzenie czy i na ile obserwowane wizualnie zmiany różnych charakterystyk klimatu są istotne statystycznie. Przeprowadzone testy wykazały, że tylko niektóre z wyznaczonych trendów są istotne statystycznie (tab. 10). Tak jest w przypadku średniej rocznej $\left(T_{a}\right)$ i maksymalnej rocznej $\left(T_{\max }\right)$ temperatury powietrza, dla których trendy zmian są istotne na poziomie 99\%. Dla $T_{a}$ współczynnik determinacji waha się od 24,5\% dla Kasprowego Wierchu do 47,9\% dla Jeleniej Góry. Wielkość dziesięcioletniego trendu $\mathrm{T}_{\mathrm{a}}$ wynosiła od $+0,2^{\circ} \mathrm{C}$ dla KW do $+0,4^{\circ} \mathrm{C}$ dla JG. W obydwu pasmach wartość trendu zmian była niższa dla stacji szczytowych niż dla stacji leżących u ich podnóża. Dla $T_{\max }$ współczynniki determinacji są niższe niż dla $T_{a^{\prime}}$ natomiast wielkości trendu zmieniały się od $+0,35^{\circ} \mathrm{C}$ na 10 lat w Zakopanem do $+0,48^{\circ} \mathrm{C} / 10$ lat w JG. Zmiany $T_{\min }$ są istotne dla JG (na poziomie $99 \%$ ) oraz dla $\mathrm{KW}$ i Z (na poziomie $95 \%$ ), a trend zmian waha się od $-0,47^{\circ} \mathrm{C}$ na 10 lat dla $\mathrm{KW}$ do $+1,68^{\circ} \mathrm{C} / 10$ lat dla JG.

Zmiany dni charakterystycznych termicznie cechują się zróżnicowaną istotnością statystyczną. W stacjach podgórskich (JG i Z) wzrasta liczba dni z $\mathrm{T}_{\max }>25^{\circ} \mathrm{C}$ (w tempie 4,4 - JG i 1,9 dni/10 lat - Z). Zmniejsza się tam natomiast liczba dni bardzo mroźnych $\left(T_{\min }<-10^{\circ} \mathrm{C}\right)$, odpowiednio w tempie $-2,7$ i $-3,7$ dnia na 10 lat. Na stacjach szczytowych obserwuje się spadek liczby dni mroźnych $\left(\mathrm{T}_{\max }<0^{\circ} \mathrm{C}\right)$ o 4,2 (Ś) i 3,5 (KW) dni na 10 lat.

Istotne statystycznie zmiany rocznych sum opadów atmosferycznych stwierdzono jedynie dla Śnieżki, a tempo tych zmian wynosi -70,8 mm/10 lat. W przypadku liczby dni z opadem na żadnej z badanych stacji nie stwierdzono istotnych statystycznie zmian. Liczba dni z pokrywą śnieżną zmniejsza się istotnie w Zakopanem o 4,5 dnia na 10 lat. Prędkość wiatru zmniejsza się istotnie w JG i Z (o 0,03-0,05 m/s na 10 lat). Wilgotność względna powietrza zmniejsza się w Jeleniej Górze o 1,1\% i w Zakopanem o 0,2\% na 10 lat.

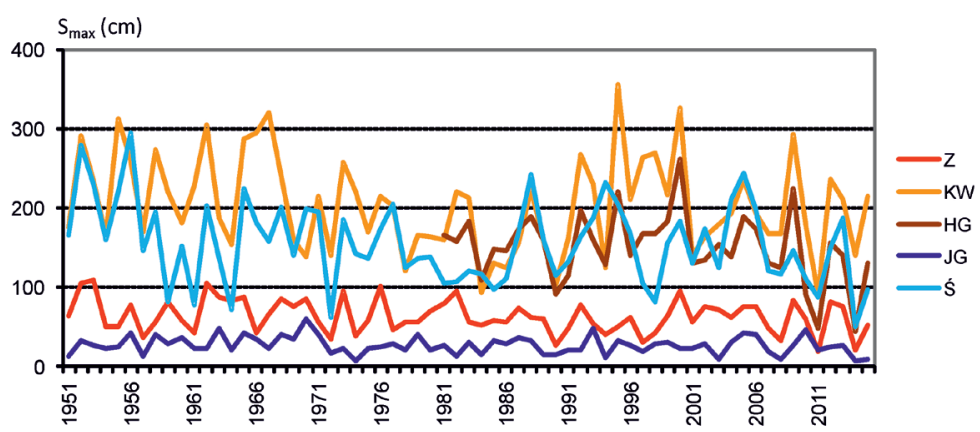

Ryc. 9. Maksymalna roczna grubość pokrywy śnieżnej $\left(\mathrm{S}_{\max }\right)$ na badanych stacjach w Tatrach i Karkonoszach, 1951-2015

Maximum annual depths of snow cover $\left(S_{\max }\right)$ at studied stations in the Tatra and Karkonosze Mts., 1951-2015 Nazwy stacji - patrz tabela 1 / For names of stations - see Table 1 
Tabela 10. Dziesięcioletnie trendy zmian wartości rocznych wybranych charakterystyk klimatu w Karkonoszach i Tatrach, 1951-2015

Ten-year trends for yearly values of selected climate characteristics in the Karkonosze and Tatra Mts., 1951-2015

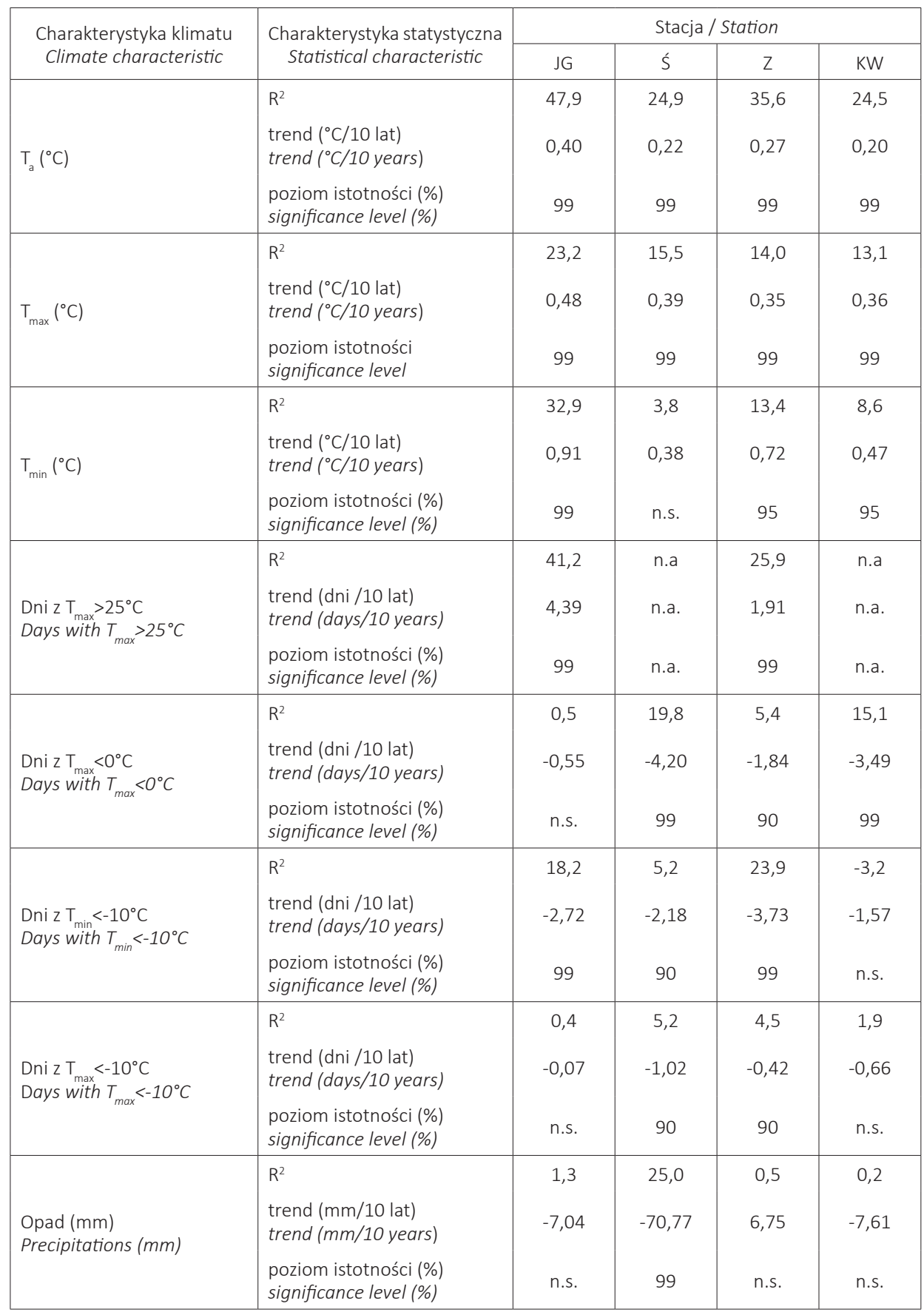




\begin{tabular}{|c|c|c|c|c|c|}
\hline $\begin{array}{l}\text { Dni z opadem } \\
\text { Precepitation days }\end{array}$ & $\begin{array}{l}\mathrm{R}^{2} \\
\text { trend (dni/10 lat) } \\
\text { trend (days/10 years) } \\
\text { poziom istotności (\%) } \\
\text { significance level (\%) }\end{array}$ & $\begin{array}{l}0,0 \\
0,18 \\
\text { n.s. }\end{array}$ & $\begin{array}{l}1,5 \\
-1,46 \\
\text { n.s. }\end{array}$ & $\begin{array}{l}2,9 \\
1,34 \\
\text { n.s. }\end{array}$ & $\begin{array}{l}2,1 \\
-1,28 \\
\text { n.s. }\end{array}$ \\
\hline $\begin{array}{l}\text { Dni z pokrywą śnieżną } \\
\text { Days with snow cover }\end{array}$ & $\begin{array}{l}\mathrm{R}^{2} \\
\text { trend (dni/10 lat) } \\
\text { trend (days/10 years) } \\
\text { poziom istotności (\%) } \\
\text { significance level (\%) }\end{array}$ & $\begin{array}{l}0,0 \\
-0,21 \\
\text { n.s. }\end{array}$ & $\begin{array}{l}0,0 \\
0,07 \\
\text { n.s. }\end{array}$ & $\begin{array}{c}9,3 \\
-4,46 \\
95\end{array}$ & $\begin{array}{l}0,5 \\
-0,59 \\
\text { n.s. }\end{array}$ \\
\hline $\begin{array}{l}\text { Prędkość wiatru }(\mathrm{m} / \mathrm{s}) \\
\text { Wind speed }(\mathrm{m} / \mathrm{s})\end{array}$ & $\begin{array}{l}\mathrm{R}^{2} \\
\text { trend ( } \mathrm{m} / \mathrm{s} / 10 \text { lat) } \\
\text { trend (m/s/10 years) } \\
\text { poziom istotności (\%) } \\
\text { significance level (\%) }\end{array}$ & $\begin{array}{c}8,8 \\
-0,05 \\
95\end{array}$ & $\begin{array}{l}3,5 \\
0,11 \\
\text { n.s. }\end{array}$ & $\begin{array}{c}8,8 \\
-0,03 \\
95\end{array}$ & $\begin{array}{r}0,8 \\
-0,03 \\
\text { n.s. }\end{array}$ \\
\hline $\begin{array}{l}\text { Wilgotność względna } \\
\text { powietrza (\%) } \\
\text { Relative air humidity (\%) }\end{array}$ & $\begin{array}{l}\mathrm{R}^{2} \\
\text { trend (\%/10 lat) } \\
\text { trend (\%/10 years) } \\
\text { poziom istotności (\%) } \\
\text { significance level (\%) }\end{array}$ & $\begin{array}{c}51,7 \\
-1,09 \\
99\end{array}$ & $\begin{array}{l}1,5 \\
-0,17 \\
\text { n.s. }\end{array}$ & $\begin{array}{c}7,5 \\
-0,23 \\
95\end{array}$ & 0,06 \\
\hline
\end{tabular}

n.s. - trendy nieistotne statystycznie, n.a. - zjawisko nie wystąpiło, nazwy stacji - patrz tabela 1

n.s. - non-significant trends, n.a. - not applicable, for names of stations - see Table 1

Dla $T_{a}$ i RR przeanalizowano także zmiany występujące w poszczególnych sezonach roku (tab. 11). W przypadku temperatury powietrza zmiany na poziomie istotności 99\% występują w miesiącach wiosennych (marzec-maj) oraz letnich (czerwiec-sierpień). Zimą (grudzień-luty) zmiany są istotne na poziomie 95\%, a jesienią (wrzesień-listopad) zmiany $\mathrm{T}_{\mathrm{a}}$ są nieistotne (poza JG). Wiosną tempo tych zmian waha się od $+0,24$ do $+0,51^{\circ} / 10$ lat, a latem od $+0,26$ do $+0,55^{\circ} \mathrm{C} / 10$ lat. Zimą tempo wzrostu temperatury powietrza jest wyraźnie mniejsze niż latem oraz wiosną i wynosi od $+0,21$ do $+0,29^{\circ} / 10$ lat.

W przypadku sezonowych sum opadów atmosferycznych zmiany są w większości nieistotne statystycznie. Wyjątkiem są sumy RR wiosną na Śnieżce (trend $+32,0 \mathrm{~mm} / 10$ lat) i w Zakopanem (+9 mm/10 lat), a także latem na Śnieżce $(-27,7$ mm/10 lat) i zimą na Kasprowym Wierchu $(-13,8 \mathrm{~mm} / 10$ lat $)$.

\section{Dyskusja}

Porównując wyniki dotyczące wieloletnich trendów zmian różnych elementów klimatu można się jedynie odnieść do zmian temperatury powietrza, opadów atmosferycznych i dni z pokrywą śnieżną. Trend zmian średniej rocznej temperatury powietrza został określony dla Tatr na $0,30-0,36^{\circ} \mathrm{C}$ na 10 lat, a dla Karkonoszy na 0,32-0,50 ${ }^{\circ} \mathrm{C} / 10$ lat. Z kolei E. Żmudzka (2009, 2010, 2011a) stwierdziła dla Tatr (Zakopane, Kasprowy Wierch), dla czterdziestolecia 1966-2006, wzrost temperatury o 0,1-0,2 $2^{\circ} \mathrm{C}$ na dekadę. Także trend zmian temperatury wyznaczony dla Śnieżki przez K. Migałę i innych (2016), na podstawie danych z okresu 1881-2010, jest niższy niż wynika z badań prezentowanych w tym artyku- 
Tabela 11. Dziesięcioletnie trendy zmian wartości sezonowych wybranych charakterystyk klimatu w Karkonoszach i Tatrach, 1951-2015

Ten-year trends for seasonal values of selected climate characteristics in the Karkonosze and Tatra Mts., 1951-2015

\begin{tabular}{|c|c|c|c|c|c|}
\hline \multirow{2}{*}{$\begin{array}{l}\text { Charakterystyka klimatu } \\
\text { Climate characteristic }\end{array}$} & \multirow{2}{*}{$\begin{array}{c}\text { Charakterystyka statystyczna } \\
\text { Statistical characteristic }\end{array}$} & \multicolumn{4}{|c|}{ Stacja / Station } \\
\hline & & $J G$ & Ś & Z & KW \\
\hline \multirow{3}{*}{$\begin{array}{l}\mathrm{T}_{a^{\prime}} \text {, wiosna }\left({ }^{\circ} \mathrm{C}\right) \\
T_{d} \text { spring }\left({ }^{\circ} \mathrm{C}\right)\end{array}$} & $\mathrm{R}^{2}$ & 42,8 & 20,8 & 25,2 & 15,4 \\
\hline & trend $\left({ }^{\circ} \mathrm{C} / 10\right.$ lat $)$ & 0,51 & 0,30 & 0,33 & 0,24 \\
\hline & $\begin{array}{l}\text { poziom istotności (\%) } \\
\text { significance level (\%) }\end{array}$ & 99 & 99 & 99 & 99 \\
\hline \multirow{3}{*}{$\begin{array}{l}\text { Opad, wiosna }(\mathrm{mm}) \\
\text { Precipitation, spring }(\mathrm{mm})\end{array}$} & $\mathrm{R}^{2}$ & 0,7 & 27,3 & 5,2 & 0,5 \\
\hline & trend (mm/10 lat) & 2,01 & 32,0 & 9,04 & 0,54 \\
\hline & $\begin{array}{l}\text { poziom istotności (\%) } \\
\text { significance level (\%) }\end{array}$ & n.s. & 99 & 90 & n.s. \\
\hline \multirow{3}{*}{$\begin{array}{l}\mathrm{T}_{a^{\prime}} \text { lato }\left({ }^{\circ} \mathrm{C}\right) \\
T_{d^{\prime}} \text { summer }\left({ }^{\circ} \mathrm{C}\right)\end{array}$} & $\mathrm{R}^{2}$ & 47,8 & 22,4 & 31,5 & 22,5 \\
\hline & $\begin{array}{l}\text { trend }\left({ }^{\circ} \mathrm{C} / 10 \text { lat }\right) \\
\text { trend }\left({ }^{\circ} \mathrm{C} / 10 \text { years }\right)\end{array}$ & 0,55 & 0,26 & 0,29 & 0,28 \\
\hline & $\begin{array}{l}\text { poziom istotności (\%) } \\
\text { significance level (\%) }\end{array}$ & 99 & 99 & 99 & 99 \\
\hline \multirow{3}{*}{$\begin{array}{l}\text { Opad, lato (mm } \\
\text { Precipitation, summer }(\mathrm{mm})\end{array}$} & $\mathrm{R}^{2}$ & 2,7 & 14,5 & 0,9 & 0,3 \\
\hline & $\begin{array}{l}\text { trend ( } \mathrm{mm} / 10 \text { lat) } \\
\text { trend (mm/10 years) }\end{array}$ & $-7,00$ & $-27,70$ & 5,72 & $-5,07$ \\
\hline & $\begin{array}{l}\text { poziom istotności (\%) } \\
\text { significance level (\%) }\end{array}$ & n.s. & 99 & n.s. & n.s. \\
\hline \multirow{3}{*}{$\begin{array}{l}T_{a^{\prime}} \text { jesień }\left({ }^{\circ} \mathrm{C}\right) \\
T_{d} \text { autumn }\left({ }^{\circ} \mathrm{C}\right)\end{array}$} & $\mathrm{R}^{2}$ & 20,2 & 2,4 & 4,3 & 1,8 \\
\hline & $\begin{array}{l}\text { trend }\left({ }^{\circ} \mathrm{C} / 10 \text { lat }\right) \\
\text { trend }\left({ }^{\circ} \mathrm{C} / 10 \text { years }\right)\end{array}$ & 0,27 & 0,10 & 0,23 & 0,01 \\
\hline & $\begin{array}{l}\text { poziom istotności (\%) } \\
\text { significance level (\%) }\end{array}$ & 99 & n.s. & n.s. & n.s. \\
\hline \multirow{3}{*}{$\begin{array}{l}\text { Opad, jesień (mm) } \\
\text { Precipitation, autumn ( } \mathrm{mm} \text { ) }\end{array}$} & $R^{2}$ & 0,1 & 3,2 & 2,3 & 2,4 \\
\hline & $\begin{array}{l}\text { trend (mm/10 lat) } \\
\text { trend (mm/10 years) }\end{array}$ & 0,77 & $-8,50$ & 6,41 & 10,6 \\
\hline & $\begin{array}{l}\text { poziom istotności (\%) } \\
\text { significance level (\%) }\end{array}$ & n.s. & n.s. & n.s. & n.s. \\
\hline \multirow{3}{*}{$\begin{array}{l}T_{a^{\prime}} \text { zima }\left({ }^{\circ} \mathrm{C}\right) \\
T_{d^{\prime}} \text { winter }\left({ }^{\circ} \mathrm{C}\right)\end{array}$} & $\mathrm{R}^{2}$ & 6,3 & 7,0 & 9,3 & 6,6 \\
\hline & $\begin{array}{l}\text { trend }\left({ }^{\circ} \mathrm{C} / 10 \text { lat }\right) \\
\text { trend }\left({ }^{\circ} \mathrm{C} / 10 \text { years }\right)\end{array}$ & 0,26 & 0,23 & 0,29 & 0,21 \\
\hline & $\begin{array}{l}\text { poziom istotności (\%) } \\
\text { significance level (\%) }\end{array}$ & 95 & 95 & 95 & 95 \\
\hline \multirow{3}{*}{$\begin{array}{l}\text { Opad, zima }(\mathrm{mm}) \\
\text { Precipitation, winter }(\mathrm{mm})\end{array}$} & $\mathrm{R}^{2}$ & 0,6 & 0,3 & 1,2 & 5,7 \\
\hline & $\begin{array}{l}\text { trend ( } \mathrm{mm} / 10 \text { lat) } \\
\text { trend (mm/10 years) }\end{array}$ & 1,19 & $-2,56$ & $-2,47$ & $-13,8$ \\
\hline & $\begin{array}{l}\text { poziom istotności (\%) } \\
\text { significance level (\%) }\end{array}$ & n.s. & n.s. & n.s. & 95 \\
\hline
\end{tabular}

*dane za lata 1981-2015, n.s. - trendy nieistotne statystycznie, nazwy stacji - patrz tabela 1 data for years 1981-2015, n.s. - non-significant trends, for names of stations - see Table 1 
le. Można zatem założyć, że to ostatnia dekada objęta tymi badaniami znacząco wpłynęła na obserwowaną wielkość trendu zmian $T_{a}$.

W badaniach uwzględniono jedynie istotne statystycznie zmiany różnych elementów klimatu. W przypadku temperatur skrajnych tylko $T_{\max }$ zmieniała się istotnie $w$ analizowanym wieloleciu. Stwierdzone trendy zmian $T_{\max }$ wynoszą w Tatrach 0,6-0,9 ${ }^{\circ} \mathrm{C} / 10$ lat, a w Karkonoszach $0,5-0,6^{\circ} \mathrm{C}$ na dekadę. Wielkości trendów $T_{\max }$ są znacząco wyższe od stwierdzonych w badaniach przez E. Żmudzką (2011b) dla Tatr oraz przez B. Głowickiego (2000) oraz J. Wibig i B. Głowickiego (2002) dla Karkonoszy. Przyczyny tych różnic należy upatrywać w tym, że w badaniach cytowanych autorów okresy obserwacji kończą się u schyłku lat 90. XX w. lub na początku XXI w. Badania prezentowane w tym artykule objęły zaś okres do roku 2015. Porównując przebiegi wartości temperatury maksymalnej widać, że lata 2001-2015 cechują się wyraźnym wzrostem $\mathrm{T}_{\mathrm{a}} \mathrm{i} \mathrm{T}_{\max }$.

Przeprowadzone badania wykazały, że opady atmosferyczne (ich sumy i liczba dni) znacząco zmieniały się jedynie na Śnieżce. Na każde 10 lat notowano tam spadek opadów o $71 \mathrm{~mm}$. W literaturze nie znaleziono informacji, jakie zmiany opadów na Śnieżce miały miejsce w innych okresach.

Zmianami pokrywy śnieżnej w Tatrach zajmowała się M. Falarz (2002). Dla okresu 1950-1999 nie stwierdziła zmian liczby dni z pokrywą na Kasprowym Wierchu, a w Zakopanem i na Hali Gąsienicowej były one niewielkie i nieistotne statystycznie. Badania B. Gądka i innych (2016) podają, że lata 1991-2015 zaznaczyły się wyraźnym trendem spadkowym grubości pokrywy śnieżnej i liczby dni z pokrywą śnieżną na Hali Gąsienicowej. Podobny trend zauważono także w prezentowanych w tej pracy badaniach. Jednak, po uwzględnieniu lat 1981-1990, gdy trend obydwu charakterystyk pokrywy śnieżnej był dodatni, okazuje się, że w całym okresie 1981-2015 ich zmiany były nieistotne statystycznie. Tylko stacja w Zakopanem i na Śnieżce wykazywały niewielki, istotny trend spadkowy tej charakterystyki. Spadek liczby dni z pokrywą śnieżną na Śnieżce był także obserwowany przez G. Urbana (2015).

Brak jest w literaturze informacji, jak zmieniały się inne elementy klimatu: wilgotność powietrza i prędkość wiatru.

\section{Podsumowanie}

Ogólne cechy klimatu Tatr i Karkonoszy są rozpoznane dość dobrze, a wyniki uzyskane dla zmienności sezonowej nie odbiegają od tych podawanych przez innych autorów, wymienionych we Wprowadzeniu. Wartością dodaną prezentowanych tu badań jest możliwość porównania niektórych cech klimatu w obydwu najwyższych pasmach górskich Polski. Stwierdzono szereg podobieństw i różnic klimatycznych pomiędzy Tatrami i Karkonoszami.

1. Średni roczny gradient wysokościowy w obydwu pasmach jest zbliżony do siebie i wynosi $-0,53^{\circ} \mathrm{C}$ na $100 \mathrm{~m}$ wysokości w Tatrach i $-0.55^{\circ} \mathrm{C}-$ w Karkonoszach.

2. Zarówno u podnóża Karkonoszy, jak i u podnóża Tatr najchłodniejszym miesiącem jest styczeń, a najcieplejszym - lipiec. Na stacjach szczytowych obserwuje się miesięczne przesunięcie najniższej i najwyższej wartości $T_{a}$ i są one notowane odpowiednio w lutym i sierpniu.

3. Wyraźnie różnią się gradienty wysokościowe $T_{\max }$. W Tatrach wynoszą one $-0,77^{\circ} \mathrm{C}$, a w Karkonoszach $-0,88^{\circ} \mathrm{C}$ na 100 m wzniesienia. 
4. Gradienty wysokościowe $T_{\min }$ w Tatrach są ujemne przez cały rok, a w Karkonoszach, w styczniu i grudniu mają wartość dodatnią, co sugeruje występowanie wtedy częstych inwersji temperatury.

5. Roczne sumy opadów są w Karkonoszach (Ś, 1212 mm) wyraźnie niższe niż w Tatrach (KW, $1721 \mathrm{~mm}$ ). Także gradient wysokościowy sum opadów jest w Karkonoszach wyraźnie niższy niż w Tatrach (odpowiednio, 38,0 i 52,9 mm na $100 \mathrm{~m}$ wzniesienia).

6. W kotlinach podgórskich najwyższe wartości wilgotności względnej powietrza występują w miesiącach jesiennych i zimowych. W partiach szczytowych okres letni cechuje się zwiększoną, a okres zimowy - zmniejszoną wilgotnością powietrza.

7. Na Śnieżce prędkość wiatru jest prawie dwukrotnie większa niż na Kasprowym Wierchu. Także dno Kotliny Jeleniogórskiej jest bardziej wietrzne niż dno Obniżenia Zakopiańskiego.

8. Pokrywa śnieżna w szczytowych partiach Tatr zalega przez 218 dni w roku, a w szczytowych partiach Karkonoszy - przez 184 dni. Grubość pokrywy śnieżnej w Tatrach jest większa niż w Karkonoszach, a w obydwu pasmach jest ona większa w miesiącach wiosennych niż w zimowych.

9. Porównanie trendów zmian różnych charakterystyk klimatu podawanych we wcześniejszych publikacjach (obejmujących krótsze okresy obserwacji) z wynikami prezentowanych tu badań wyraźnie dowodzi, że początek XXI w. cechuje się bardzo wyraźnym ociepleniem klimatu w Tatrach i Karkonoszach.

Praca nie obejmuje całości tematyki związanej z klimatem obydwu pasm górskich. Wskazuje natomiast obszary tematyczne, które wymagają dalszych, pogłębionych badań porównawczych.

\section{Piśmiennictwo}

Baranowski J., 1999, Wpływ rzeźby i pokrycia terenu na warunki wietrzne w Tatrach Wysokich na przykładzie Hali Gqsienicowej, [w:] A. Kotarba, A. Kozłowska (red.), Badania geoekologiczne w otoczeniu Kasprowego Wierchu, Prace Geograficzne, 174, IGiPZ PAN, Warszawa, s. 105-120.

Baranowski J., 2003a, Pochłonięte promieniowanie słoneczne w Tatrach w otoczeniu Hali Gqisienicowej, [w:] K. Błażejczyk, B. Krawczyk, M. Kuchcik (red.), Postępy w badaniach klimatycznych i bioklimatycznych, Prace Geograficzne, 188, IGiPZ PAN, Warszawa, s. 131-144.

Baranowski J., 2003b, Dynamika zmian dobowych i zróżnicowanie przestrzenne temperatury powietrza na Hali Gąsienicowej, Przegląd Geograficzny, 75, 2, s. 271-286.

Barry R.G., Van Wie C.C., 1974, Topo- and microclimatology in alpine areas, [w:] J.D. Ives, R.G. Barry (red.), Arctic and Alpine Environments, Methuen, London, s. 73-83.

Błażejczyk K., Baranowski J., Błażejczyk A., Szmyd J., 2013, Klimat i bioklimat Hali Gq̨sienicowej, [w:] Z. Rączkowska, A. Kotarba (red.), Dolina Suchej Wody w Tatrach. Środowisko i jego współczesne przemiany, Prace Geograficzne, 239, IGiPZ PAN, Warszawa, s. 67-95.

Cebulak E., 1983, Maximum daily rainfalls in the Tatra Mountains and Podhale Basin, Zeszyty Naukowe UJ, Prace Geograficzne, 57, s. 337-343.

Dąbrowska K., Guzik M. (red.), 2015, Atlas Tatr. Przyroda nieożywiona, Tatrzański Park Narodowy, Zakopane. 
Falarz M., 2000-2001, Zmienność wieloletnia występowania pokrywy śnieżnej w polskich Tatrach, Folia Geographica, Series Geographica Physica, 31-32, s. 101-123.

Falarz M., 2002, Klimatyczne przyczyny zmian i wieloletniej zmienności występowania pokrywy śnieżnej w polskich Tatrach, Przegląd Geograficzny, 74, 1, s. 83-106.

Falarz M., 2007, Snow cover variability in Poland in relation to the macro- and mesoscale atmospheric circulation in the 20th century, International Journal of Climatology, 27, s. 2069-2081.

Gądek B., Grabiec M., Rączkowska Z., Maciata B., 2016, Variability of the snow avalanche danger in the Tatra Mountains during the past nine decades, Geographia Polonica, 89, 1, s. 65-77.

Głowicki B., 1998, Wieloletnia seria pomiarów temperatury powietrza na Śnieżce, [w:] Geoekologiczne Problemy Karkonoszy, 1, Wydawnictwo Acarus, Poznań, s. 117-123.

Głowicki B., 2000, 20th century variability to daily maxima and minima of air temperature in the Sudetic Mountains, Geographia Polonica, 73, 2, s. 111-116.

Hess M., 1965, Piętra klimatyczne w Polskich Karpatach Zachodnich, Zeszyty Naukowe Uniwersytetu Jagiellońskiego, Prace Geograficzne, 11, Kraków.

Konček M. (red.), 1974, Klimat Tatr, Folia Geographica, 4, Slovenska Akademia Vied, Bratislava.

Kotarba A., 2013, Rzeźba system dolinnego Suchej Wody i Pańszczycy, [w:] Z. Rączkowska, A. Kotarba (red.), Dolina Suchej Wody w Tatrach. Środowisko i jego współczesne przemiany, Prace Geograficzne, 239, IGiPZ PAN, Warszawa, s. 15-34.

Kozak J.L., Łepko M., 2015, Wieloletnia zmienność grubości pokrywy śnieżnej w okolicy Szczyrku, Inżynieria Ekologiczna, 41, s. 153-159.

Kozłowska A., 2013, Roślinność Doliny Suchej Wody, [w:] Z. Rączkowska, A. Kotarba (red.), Dolina Suchej Wody w Tatrach. Środowisko i jego współczesne przemiany, Prace Geograficzne, 239, IGiPZ PAN, Warszawa, s. 127-136.

Kozłowska A., Rączkowska Z., 1996, The spatial relations of relief and vegetation, Studia Geomorphologica Carpatho-Balcanica, 30, s. 117-128.

Kozłowska A., Rączkowska Z., 1999, Środowisko wysokogórskie jako system wzajemnie powiqzanych elementów, [w:] A. Kotarba, A. Kozłowska (red.), Badania geoekologiczne w otoczeniu Kasprowego Wierchu, Prace Geograficzne, 174, IGiPZ PAN, Warszawa, s. 121-127.

Krąż P., Wójcik S., 2015, Mikroregiony fizycznogeograficzne polskiej części Bruzdy Podtatrzańskiej i Pogórzy Przedtatrzańskich, [w:] J. Liro, M. Liro, P. Krąż (red.), Współczesne problemy i kierunki badawcze w geografii, 3, IGiGP UJ, Kraków, s. 131-147.

Migała K., 2005, Piętra klimatyczne w górach Europy a problem zmian globalnych, Acta Universitatis Wratislaviensis, 2718, Studia Geograficzne, 78, Wydawnictwo Uniwersytetu Wrocławskiego, Wrocław.

Migała K., Czerwiński J., 2004, Das Observatorium auf der Schneekoppe (Śnieżka) im Riesengebirge (Karkonosze) 1603 m, westliche Sudeten, Polen, 100. Jahresbericht des Sonnblick - Vereines für das Jahr 2002, Wien, s. 24-28.

Migała K., Urban G., Tomczyński K., 2016, Long-term air temperature variation in the Karkonosze mountains according to atmospheric circulation, Theoretical and Applied Climatology, 125, s. 337-351.

Niedźwiedź T., 1992, Climate of the Tatra Mountains, Mountain Research and Development, 12, 2, s. 131-146.

Niedźwiedź T., 1996, Wieloletnia zmienność temperatury powietrza i opadów w Tatrach, [w:] A. Kotarba (red.), Przyroda Tatrzańskiego Parku Narodowego a Człowiek, 1, Nauki o Ziemi, Materiały I Ogólnopolskiej Konferencji, Zakopane, 6-9 października 1995, Kraków-Zakopane, s. 161-163. 
Niedźwiedź T., 2003, Extreme precipitation events on ten northern side of the Tatra Mountains, Geographia Polonica, 76, 2, s. 13-21.

Niedźwiedź T., 2004, Rekonstrukcja warunków termicznych lata w Tatrach od 1550 roku, [w:] A. Kotarba (red.), Rola małej epoki lodowej w przekształcaniu środowiska przyrodniczego Tatr, Prace Geograficzne, 197, IGiPZ PAN, Warszawa, s. 57-88.

Niedźwiedź T., 2006, Zmienność temperatury powietrza w Tatrach w porównaniu z Karpatami Południowymi i Alpami, [w:] A. Kotarba, W. Borowiec (red.), Tatrzański Park Narodowy na tle innych górskich terenów chronionych, 1, Nauki o Ziemi, Zakopane-Kraków, s. 13-21.

Obrębska-Starlowa B., Trepińska J., Niedźwiedź T., Bednarz Z., 1996, Trendy zmian klimatycznych w Tatrach Polskich, [w:] A. Kotarba (red.), Przyroda Tatrzańskiego Parku Narodowego a Człowiek, 1, Nauki o Ziemi, Materiały I Ogólnopolskiej Konferencji, Zakopane, 6-9 października 1995, Kraków-Zakopane, s. 168-170.

Rączkowska Z., 2013, Współczesne procesy morfogenetyczne, [w:] Z. Rączkowska, A. Kotarba (red.), Dolina Suchej Wody w Tatrach. Środowisko i jego współczesne przemiany, Prace Geograficzne, 239, IGiPZ PAN, Warszawa, s. 35-48.

Sobik M., Błaś M., Migała M., Godek M., Nasiołkowski T., 2013, Klimat, [w:] R. Knapik, A. Raj (red.), Przyroda Karkonoskiego Parku Narodowego, KPN, Jelenia Góra, Wydawnictwo Dimograf, Bielsko-Biała, s. 147-186.

Trepińska J., 2002, Górskie klimaty, Wydwnictwo IGiGP UJ, Kraków.

Urban G., 2015, Zaleganie pokrywy śnieżnej i jego zmienność w polskiej części Sudetów i na ich przedpolu, Przegląd Geograficzny, 87, 3, s. 497-516.

Ustrnul Z., Walawender E., Czekierda D., Štasny P., Lapin M., Mikulova K., 2015, Opady atmosferyczne i pokrywa śnieżna, [w:] K. Dąbrowska, M. Guzik (red.), Atlas Tatr. Przyroda nieożywiona, Tatrzański Park Narodowy, Zakopane, arkusz II.3, mapy 1, 5.

Wibig J., Głowicki B., 2002, Trends of minimum and maximum temperature in Poland, Climate Research, 20, s. 123-133.

Yoshino M.M., 1984, Thermal belt and cold air drainage on the mountain slope and cold air lakes in the basin at quiet, clear night, GeoJournal, 8, 3, s. 230-250.

Żmudzka E., 2009, Changes of thermal conditions in the Polish Tatra Mountains, Landform Analysis, 10, s. $140-146$.

Żmudzka E., 2010, Współczesne zmiany wielkości i charakteru opadów w Tatrach, [w:] A. Kotarba (red.), Nauka a zarzqdzanie obszarem Tatr i ich otoczeniem, tom 1, Tatrzański Park Narodowy, Polskie Towarzystwo Przyjaciół Nauk o Ziemi, Zakopane, s. 157-164.

Żmudzka E., 2011a, Współczesne zmiany klimatu wysokogórskiej części Tatr, Prace i Studia Geograficzne, 47, s. 217-226.

Żmudzka E., 2011b, Contemporary climate changes in the high mountain part of the Tatras, Miscellanea Geographica, 15, s. 93-102.

Żmudzka E., Nejedlik P., Mikulova K., 2015, Temperatura, wskaźniki termiczne, [w:] K. Dąbrowska, M. Guzik (red.), Atlas Tatr. Przyroda nieożywiona, Tatrzański Park Narodowy, Zakopane, arkusz II.2, mapa 1. 


\section{Summary}

Mountain areas are ecosystems very vulnerable to fluctuations and changes of climate. As a consequence, research into climate and climate change in Poland's Karkonosze and Tatra Mountains has been ongoing for several years now, and has already yielded essential information regarding these highest ranges in Poland. However, there remains a paucity of research comparing features of climate in the two chains of mountains. In consequence, the work detailed here has sought to compare key climate characteristics in these ranges, as well as their seasonal and multiannual changes over the period 1951-2015.

The research is based on daily meteorological records from the network of Poland's IMGW-PIB (Institute of Meteorology and Water Management - National Research Institute). In the case of the Karkonosze Mts., it was the meteorological stations at Śnieżka (Ś, $1603 \mathrm{~m}$ a.s.I.) and Jelenia Góra (JG, $344 \mathrm{~m}$ a.s.I.) that were chosen; while in the Tatras the selected stations were on Kasprowy Wierch (KW, 1990 m a.s.I.) and in Zakopane (Z, $857 \mathrm{~m}$ a.s.I.). Additionally, the station at Hala Gąsienicowa (HG, $1520 \mathrm{~m}$ a.s.I.) was considered in line with data available for the shorter 1981-2015 period.

The research took account of daily data on air temperature, relative humidity of the air, wind speed, precipitation and snow cover. Specifically, the climate characteristics calculated and analysed by reference to mean multiannual, yearly and seasonal values related to air temperature $\left(T_{a}\right)$, maximum temperature $\left(T_{\max }\right)$, minimum temperature $\left(T_{\min }\right)$, precipitation totals $(R R)$ and maximum snow depth $\left(S_{\max }\right)$. Further analysis related to numbers of days with precipitation $\left(R R_{\text {days }}\right)$ and snow cover $\left(S_{\text {days }}\right)$, as well as numbers of days with specific air temperatures described as hot $\left(T_{\max }>25^{\circ} \mathrm{C}\right)$, frosty $\left(T_{\max }<0^{\circ} \mathrm{C}\right)$, very frosty $\left(\mathrm{T}_{\min }<-10^{\circ} \mathrm{C}\right)$ and icy $\left(\mathrm{T}_{\max }<-10^{\circ} \mathrm{C}\right)$. To determine the statistical significance of any trends noted among the studied climate elements, the STATGRAPHICS 7.2. software package was applied.

The results dealing with seasonal climate variability are similar to those reported previously by other authors. However, the added value of this research is the possibility of comparing various climate elements directly, in relation to the two highest ranges of mountains in Poland. In the event, the several climate similarities and differences between the Tatra and Karkonosze Mountains were found to include:

1. mean annual altitudinal gradients for air temperature that are similar for the Tatras $\left(-0.53^{\circ} \mathrm{C}\right.$ per $\left.100 \mathrm{~m}\right)$ and the Karkonosze $\left(-0.55^{\circ} \mathrm{C} / 100 \mathrm{~m}\right)$,

2. the coldest month at the bottoms of both ridges being January, and the warmest July; while top stations feature a 1-month delay, in the sense that February and August are the coldest and warmest months respectively,

3. differing altitudinal gradients of maximum temperature, with the Tatras reporting $-0.77^{\circ} \mathrm{C}$ per $100 \mathrm{~m}$ and the Karkonosze $--0.88^{\circ} \mathrm{C} / 100 \mathrm{~m}$,

4. yearly precipitation totals and altitudinal precipitation gradients that are significantly less well-marked in the Karkonosze than in the Tatras (respectively 1212 and $1721 \mathrm{~mm}$, as well as 38.0 and $52.9 \mathrm{~mm}$ per $100 \mathrm{~m}$ ),

5. more precipitation days on Śnieżka than Kasprowy Wierch (237 v 227, notwithstanding rather low precipitation totals),

6. relative humidity of air that is highest in autumn and winter below the two ranges, while being highest at the summits in summer, 
7. a wind speed in the Karkonosze that is higher than in the Tatras; i.e. $12.2 \vee 6.6 \mathrm{~m} / \mathrm{s}$ at the summits, and 2.5 and $1.4 \mathrm{~m} / \mathrm{s}$ respectively down below,

8. snow cover of 218 days duration at the top of the Tatra Mountains, as opposed to 187 days on Mt. Śnieżka.

The study also considered multiannual changes in elements of climate over the 1951-2015. Trends achieving statistical significance (with 99, 95\% or 90\% confidence levels) were confined to just some of the characteristics and stations (see Tables 10 and 11). Nevertheless, the Tatra and Karkonosze Mountains have experienced an increase in mean annual air temperature - respectively of $0.20-0.27$ and $0.22-0.40^{\circ} \mathrm{C}$ each consecutive 10-year period. Significant changes were also observed for maximum temperature, $T_{\max }$ equal to $0.35-0.36^{\circ} \mathrm{C}$ per 10 years in the Tatras and $0.4-0.5^{\circ} \mathrm{C}$ per decade in the Karkonosze.

In the case of precipitation totals the only significant change in value is that noted for Śnieżka top, where the trend is a downward one equal to some $71 \mathrm{~mm}$ per 10 years.

Where snow cover was concerned, the only effect was a slight decrease in the number of snowy days recorded at Zakopane, located just below the Tatra Mountains. 